\title{
Parallel Inhibition of Dopamine Amacrine Cells and Intrinsically Photosensitive Retinal Ganglion Cells in a Non-Image-Forming Visual Circuit of the Mouse Retina
}

\author{
Helen E. Vuong, ${ }^{1,2,3}$ Claudia N. Hardi, ${ }^{1}$ Steven Barnes, ${ }^{1,5,6,7 *}$ and Nicholas C. Brecha ${ }^{1,2,3,4,7 \star}$ \\ Departments of ${ }^{1}$ Neurobiology and ${ }^{2}$ Molecular, Cellular, and Integrative Physiology, ${ }^{3}$ Stein Eye Institute, and ${ }^{4} \mathrm{CURE}$ : Digestive Diseases Research Center, \\ David Geffen School of Medicine at UCLA, University of California Los Angeles, Los Angeles, California 90095, Departments of 5 Physiology and Biophysics \\ and ${ }^{6}$ Ophthalmology and Visual Sciences, Dalhousie University, Halifax, Nova Scotia B3H 4R2, Canada, and ${ }^{7}$ Veterans Administration Greater Los Angeles \\ Healthcare System, Los Angeles, California 90073
}

\begin{abstract}
An inner retinal microcircuit composed of dopamine (DA)-containing amacrine cells and melanopsin-containing, intrinsically photosensitive retinal ganglion cells (M1 ipRGCs) process information about the duration and intensity of light exposures, mediating light adaptation, circadian entrainment, pupillary reflexes, and other aspects of non-image-forming vision. The neural interaction is reciprocal:M1 ipRGCs excite DA amacrine cells, and these, in turn, feedinhibition back onto M1 ipRGCs. Wefound that theneuropeptide somatostatin [somatotropin releaseinhibiting factor(SRIF)] also inhibits the intrinsic light response of M1 ipRGCs and postulated that, to tune the bidirectional interaction of M1 ipRGCs and DA amacrine cells, SRIF amacrine cells would provide inhibitory modulation to both cell types. SRIF amacrine cells, DA amacrine cells, and M1 ipRGCs form numerous contacts. DA amacrine cells and M1 ipRGCs express the SRIF receptor subtypes sst $_{2 \mathrm{~A}}$ and sst $_{4}$ respectively. SRIF modulation of the microcircuit was investigated with targeted patch-clamp recordings of DA amacrine cells in TH-RFP mice and M1 ipRGCs in OPN4-EGFP mice. SRIF increases $\mathrm{K}^{+}$currents, decreases $\mathrm{Ca}^{2+}$ currents, and inhibits spike activity in both cell types, actions reproduced by the selective $s_{2 \mathrm{~A}}$ agonist L-054,264 $\left(N-\left[(1 R)-2-\left[\left[\left[\left(1 S^{*}, 3 R^{*}\right)-3\right.\right.\right.\right.\right.$ (aminomethyl)cyclohexyl]methyl]amino]-1-(1H-indol-3-ylmethyl)-2-oxoethyl]spiro[ $1 H$-indene-1,4'-piperidine]-1'-carboxamide) in DA amacrine cells and the selective sst ${ }_{4}$ agonist L-803,087 ( $N^{2}$-[4-(5,7-difluoro-2-phenyl-1H-indol-3-yl)-1-oxobutyl]-L-arginine methyl ester trifluoroacetate) in M1 ipRGCs. These parallel actions of SRIF may serve to counteract the disinhibition of M1 ipRGCs caused by SRIF inhibition of DA amacrine cells. This allows the actions of SRIF on DA amacrine cells to proceed with adjusting retinal DA levels without destabilizing light responses by M1 ipRGCs, which project to non-image-forming targets in the brain.
\end{abstract}

Key words: amacrine cells; dopamine; interneuron; melanopsin ipRGCs; microcircuit; somatostatin

Significance Statement

Amacrine cells form multiple microcircuits in the inner retina to mediate visual processing, although their organization and function remain incompletely understood. The somatostatin [somatotropin release inhibiting factor (SRIF)]- and dopamine (DA)-releasing amacrine cells act globally, and, in this study, they are shown to interact and modulate the light response of intrinsically photosensitive retinal ganglion cells (ipRGCs). SRIF amacrine cells target both DA amacrine cells and M1 ipRGCs for inhibition. The parallel actions of SRIF may serve to compensate for the loss of DA-mediated inhibition of M1 ipRGCs. This inhibitory tuning is of particular importance because the DA system mediates a broad range of light adaptational actions in the retina and M1 ipRGCs project to brain areas that influence sleep, mood, cognition, circadian entrainment, and pupillary reflexes.

\section{Introduction}

Microcircuits in the retina take part in the simultaneous processing of different features of visual information to generate the multiple channels that mediate visual function. More than 30 different types of interneurons called amacrine cells modulate the output of ganglion cells, the projection neurons of the retina (Masland, 2012). Dopamine (DA)-releasing amacrine cells are a particularly important inhibitory interneuron in this regard, hav- 
ing widespread influence on virtually all retinal cells and the visual information channels carried by ganglion cells to higher brain regions (Dowling, 1991; Witkovsky, 2004).

This report investigates the regulation of a mammalian retinal microcircuit that mediates reciprocal signaling between DA amacrine cells and type 1 melanopsin-containing intrinsically photosensitive retinal ganglion cells (M1 ipRGCs; Sakamoto et al., 2005; Zhang et al., 2008; Schmidt et al., 2011; Van Hook et al., 2012; Atkinson et al., 2013; Dkhissi-Benyahya et al., 2013). Previous studies have shown numerous appositions between DA amacrine cell processes and M1 ipRGC dendrites in the inner plexiform layer (IPL) that may be unconventional synapses (Belenky et al., 2003; Viney et al., 2007; Vugler et al., 2007; Dumitrescu et al., 2009; Zhang et al., 2012) and that DA, acting through $D_{1}$ receptors, inhibits M1 ipRGCs (Zhang et al., 2008; Van Hook et al., 2012; Hu et al., 2013).

In mammalian and chick retinas, DA amacrine cells regulate integral retinal networks that mediate light adaptation, circadian rhythms, color vision, contrast sensitivity, and visual acuity (Dowling, 1991; Masland, 2001; Ko et al., 2003; Witkovsky, 2004). DA amacrine cell activity leading to DA release occurs in response to light, steady background illumination, and prolonged darkness (Zhang et al., 2007; Contini et al., 2010; Newkirk et al., 2013). M1 ipRGCs provide excitatory drive to DA amacrine cells (Zhang et al., 2008, 2012; Atkinson et al., 2013). This was shown in the rd1 mouse retina, which lacks rod and cone photoreceptors, and wild-type mouse retina treated with $\mathrm{L}(+)-2-$ amino-4-phosphonobutyrate (L-AP-4; an agonist of the mGluR6 receptor that blocks signaling between photoreceptors and $\mathrm{ON}$ bipolar cells), in which DA amacrine cells exhibit sustained light responses mediated by AMPA- and kainate-type glutamate receptors, which are activated by glutamate release from ipRGC dendrites.

The reciprocal connectivity between DA amacrine cells and M1 ipRGCs is poised to provide critical regulation of non-imageforming visual functions. Thus, it is important to determine how additional inputs from other retinal neurons could coordinate the light-dependent responses of this microcircuit (Gustincich et al., 1997; Zhang et al., 2007). Previous work has indicated that an additional, unidentified amacrine cell subtype inhibits light responses of DA amacrine cells and M1 ipRGCs (Perez-Leon et al., 2006; Wong et al., 2007; Atkinson et al., 2013; Newkirk et al., 2013). We identify a wide-field amacrine cell expressing somatotropin release inhibiting factor (somatostatin or SRIF) that mediates inhibition of the DA amacrine cell-M1 ipRGC microcircuit.

SRIF is synthesized and released by a subset of amacrine cells that mainly ramify in stratum 1 of the IPL in mammalian retinas (Tornqvist et al., 1982; White et al., 1990; Rickman et al., 1996; Cristiani et al., 2002). The effects of SRIF are global and mediated by G-protein-coupled receptor subtypes $\left(\right.$ sst $\left._{1}-\mathrm{sst}_{5}\right)$ identified in

Research-Nova Scotia Health Research Foundation Regional Partnership Program MOP-10968 (S.B.), a Natural Sciences and Engineering Research Council of Canada Discovery Award 194640 (S.B.), and a Whitcome Summer Undergraduate Research Fellowship (C.N.H.). N.C.B. is a Veterans Administration Career Research Scientist. We thank Dr. Douglas McMahon for providing the TH-RFP mouse line, Dr. David Berson for providing the OPN4 -EGFP mouse line, and Drs. Kristopher G. Sheets, Arlene A. Hirano, and Luis Pérez de Sevilla Müller for assistance with data interpretation and comments on this manuscript.

The authors declare no competing financial interests.

*S.B. and N.C.B. are co-senior authors.

Correspondence should be addressed to Dr. Nicholas C. Brecha, Department of Neurobiology, David Geffen School of Medicine at UCLA, University of California Los Angeles, 10833 Le Conte Avenue, Los Angeles, CA 90095-1763. E-mail:nbrecha@ucla.edu.

DOI:10.1523/JNEUROSCI.3382-15.2015

Copyright $\odot 2015$ the authors $\quad 0270-6474 / 15 / 3515956-16 \$ 15.00 / 0$ rod bipolar cells, horizontal cells, glycine- and tyrosine hydroxylase (TH)-immunoreactive amacrine cells, and ganglion cells (Johnson et al., 1998, 1999, 2000; Cristiani et al., 2002). In vertebrate retinas, SRIF signaling cascades are generally inhibitory, modulating multiple voltage-gated ion currents in retinal cells (Akopian et al., 2000; Petrucci et al., 2001; Jian et al., 2009; Farrell et al., 2010; Chen et al., 2014).

We mapped the unusually close relationships made by the wide-field SRIF and DA amacrine cell processes in the IPL, as well as their numerous contacts with M1 ipRGCs. By visualizing specific $s_{2 \mathrm{~A}}$ and $\mathrm{sst}_{4}$ receptors on DA amacrine cells and M1 ipRGCs, respectively, we also show potential sites of interaction with released SRIF. We investigated SRIF modulation of the intrinsic properties of DA amacrine cells and the intrinsic properties and photoresponsivity of M1 ipRGCs using targeted whole-cell patch-clamp recordings of M1 ipRGCs in opsin 4 (OPN4)-enhanced green fluorescent protein (EGFP) retinas and DA amacrine cells in TH-red fluorescent protein (RFP) retinas. Our results establish the anatomical and physiological substrates through which SRIF amacrine cells regulate in parallel both DA amacrine cell and M1 ipRGC signaling, revealing a novel model of dual wide-field amacrine cell regulation within a retinal microcircuit that mediates light adaptation and non-image-forming vision.

\section{Materials and Methods}

Animals

Animal housing and all experiments were in accordance with the guidelines and policies for the welfare of experimental animals prescribed by the University of California Los Angeles (UCLA) Animal Research Committee, UCLA Division of Laboratory Animal Medicine, and the U.S. Public Health Service Policy on Humane Care and Use of Laboratory Animals.

Retinas were collected from male and female C57BL/6J or OPN4EGFP mice (4-6 weeks old) for immunohistochemistry studies. C57BL/6J mice were from either The Jackson Laboratory or the UCLA Division of Laboratory Animal Medicine. Transgenic mice expressing RFP under the TH promoter (Zhang et al., 2004) or EGFP under the OPN4 promoter (Schmidt et al., 2008) were labeled DA amacrine cells or ipRGCs, respectively. The OPN4-EGFP mouse line was generated using an FVB/NCr genetic background. TH-RFP and OPN4-EGFP mice were used for patch-clamp electrophysiology. The mice were maintained on a $12 \mathrm{~h} \mathrm{light/dark} \mathrm{cycle.}$

Primers used for detecting RFP were $5^{\prime}$-GCA CCT TGA AGC GCA TGA A- ${ }^{\prime}$ and 5'-CAC TTT GTT ACA TGG GCT GGG-3' . A predicted band at $\sim 590 \mathrm{bp}$ indicated the presence of the transgene. Primers used for detecting GFP were 5'-CACATGAAGCAGCACGACTTCT-3' and 5'-GGGTGTTCTGCTGGTAGTGGTC-3'. A predicted band $331 \mathrm{bp}$ indicated the presence of the transgene.

\section{Tissue preparation}

Mice were anesthetized deeply using 1-3\% isoflurane (IsoFlo; Abbott Laboratories) and killed by decapitation or cervical dislocation. Eyes were enucleated, and the cornea and lens were removed.

Vertical retinal sections. Eyecups were immersion fixed in $4 \%(\mathrm{w} / \mathrm{v})$ paraformaldehyde (PFA) in $0.1 \mathrm{~m}$ phosphate buffer (PB), $\mathrm{pH} 7.4$, for 15-60 min. Eyecups were subsequently washed in $0.1 \mathrm{M}$ PB for $30 \mathrm{~min}$ and stored in $30 \%$ sucrose overnight at $4^{\circ} \mathrm{C}$ and then embedded in optimal cutting temperature medium (Sakura Finetek) and sectioned vertically at $12 \mu \mathrm{m}$. Retinal sections were placed onto gelatin-coated slides and stored at $-20^{\circ} \mathrm{C}$ until used for immunohistochemistry.

Whole-mount retinal preparation. The retinas were removed from the eyecups, and four small incisions were made to lay the retina flat. Retinas were mounted, ganglion cell layer (GCL) up, onto nitrocellulose membrane filters (catalog \#HABP04700; Millipore) and immersed for 30-60 $\min$ in $4 \%$ PFA in $0.1 \mathrm{M} \mathrm{PB}$ at room temperature. Whole-mounted retinas were then washed and processed for immunohistochemistry. 
Table 1. Antibodies used in this study

\begin{tabular}{|c|c|c|c|c|c|c|}
\hline Antibody & Host & Antigen & Source & Catalog\# & Dilution & Reference \\
\hline Somatostatin & Rat & $\begin{array}{l}\text { Peptide corresponding to } \\
\text { amino acids } 1-14 \text { of cyclic somatostatin } \\
\text { conjugated to bovine thyroglobulin } \\
\text { using carbodiimide }\end{array}$ & Millipore & MAB354 & $1: 100$ & Cristiani et al., 2002 \\
\hline Melanopsin & Rabbit & $\begin{array}{l}\text { Peptide corresponding to } \\
\text { residues E (455) QKSKTPKTKRHLPSLDRRM } \\
\text { (474) of rat melanopsin }\end{array}$ & Thermo Fisher Scientific & PA1-781 & $1: 250$ & Pérez de Sevilla Müller et al., 2014 \\
\hline $\mathrm{sst}_{2 \mathrm{~A}}$ & Rabbit & $\begin{array}{l}\text { Peptide corresponding to } \\
\text { the C terminus; PETQRTLLNGDL-QTSI }\end{array}$ & Gramsch & SS-800 & $1: 2000$ & Johnson et al., 2000 \\
\hline sst $_{4}$ & Rabbit & $\begin{array}{l}\text { Peptide corresponding to the } C \\
\text { terminus; CQQEPVQAEPGCKQVPFTKT TTF }\end{array}$ & $\begin{array}{l}\text { Brecha Laboratory, University of } \\
\text { California Los Angeles }\end{array}$ & & $1: 3000$ & Farrell et al., 2010 \\
\hline
\end{tabular}

\section{Immunohistochemistry}

Vertical retinal sections. Retinal sections were processed for immunohistochemical labeling using an indirect immunofluorescence method (Vuong et al., 2015). Frozen retinal sections were thawed for $10 \mathrm{~min}$ at $37^{\circ} \mathrm{C}$ on a warming plate and then washed three times for $10 \mathrm{~min}$ with 0.1 $\mathrm{M} P B, \mathrm{pH}$ 7.4. Sections were then incubated in a blocking solution of $10 \%$ normal goat serum (NGS), $1 \%$ bovine serum albumin (BSA), and $0.5 \%$ Triton X-100 in $0.1 \mathrm{M} \mathrm{PB}$ for $1 \mathrm{~h}$ at room temperature. After removal of the blocking solution, the primary antibody solution was immediately added to the sections and incubated for $12-16 \mathrm{~h}$ at $4^{\circ} \mathrm{C}$. Primary antibody solution contained 3\% NGS, $1 \%$ BSA, $0.05 \%$ sodium azide, and $0.5 \%$ Triton X-100 in $0.1 \mathrm{M}$ PB. Retinal sections were then washed three times for $10 \mathrm{~min}$ in $0.1 \mathrm{M} \mathrm{PB}$. The sections were then incubated with their corresponding secondary antibodies goat anti-rabbit, anti-rat, or antimouse conjugated to Alexa Flour 568 or 488 (1:1000; Invitrogen) for $2 \mathrm{~h}$ at room temperature. The secondary antibody was removed, and sections were washed three times in $0.1 \mathrm{M} \mathrm{PB}$ for $10 \mathrm{~min}$ per wash. Sections were air dried and mounted using Aqua Poly/Mount (Polysciences). To control for nonspecific binding of the secondary antibody, the primary antibodies were omitted in the single-labeling studies.

Whole-mounted retina. Whole-mounted retinas were processed for immunohistochemical labeling with a protocol similar to that used for vertical sections. Whole-mounted retinas were fixed, washed in $0.1 \mathrm{M} \mathrm{PB}$, and then incubated in blocking solution overnight at $4^{\circ} \mathrm{C}$. The retinas were then transferred to primary antibody solution and incubated for $5 \mathrm{~d}$ at $4^{\circ} \mathrm{C}$. Retinas were washed in $0.1 \mathrm{M} \mathrm{PB}$ for three times for $20 \mathrm{~min}$ each time and then incubated in secondary antibodies for $2 \mathrm{~d}$ at $4^{\circ} \mathrm{C}$. After removal from the secondary antibody solution, retinas were washed three times in $0.1 \mathrm{M}$ PB for $20 \mathrm{~min}$ for each wash. Similar to the retinal sections, whole-mounted retinas were briefly air dried and mounted using Aqua Poly/Mount (Polysciences).

For immunohistochemistry controls, all antibodies were tested using mouse retina in single immunostaining experiments to confirm specificity and optimize concentration before performing any double-labeling experiments. Experiments omitting primary antibodies eliminated specific immunostaining. For double-labeling controls, one of the two primary antibodies used for double labeling was omitted during the primary incubation step. In this case, only the immunostaining by the remaining primary antibody was detected.

Antibodies. The following antibodies were used in this study: (1) rat monoclonal antibody against somatostatin (SRIF; 1:100; MAB354, clone YC7; Millipore); (2) rabbit polyclonal antibody against melanopsin (1: 250; PA1-781; Thermo Fisher Scientific); (3) mouse monoclonal antibody against TH (1:2000; MAB5280, clone 2/40/15; Millipore); (4) rabbit polyclonal antibody against sst $_{2 \mathrm{~A}}$ (1:2000; SS-800; Gramsch); and (5) rabbit polyclonal antibody against $\mathrm{sst}_{4}(1: 3000)$, developed using a synthetic peptide directed to the $\mathrm{C}$ terminus of the rat sst ${ }_{4}$ receptor (amino acids 362-384; Farrell et al., 2010; Table 1).

\section{Confocal image acquisition}

The immunostaining images were acquired with a Zeiss LSM510 Meta or LSM710 confocal laser scanning microscope (Carl Zeiss) equipped with
488, 543, and $633 \mathrm{~nm}$ laser lines. Confocal scans were captured using a C-Apochromat $40 \times, 1.2$ numerical aperture (NA) corrected waterimmersion objective or a Plan-Apochromat $63 \times, 1.4$ NA corrected oilimmersion objective. To make the $2 \mathrm{D}$ figure panels of retinal transverse sections and whole mounts, projections of two to three images $(2048 \times$ 2048 pixels) with a total of $0.9-1.0 \mu \mathrm{m}$ thickness (overlapping $z$-axis steps between 0.3 and $0.5 \mu \mathrm{m}$ ) were collected and adjusted for brightness and contrast in Adobe Photoshop CS2 version 9.02 (Adobe Systems). To make the $3 \mathrm{D}$ reconstructions of retinal whole-mount image stacks $(z$-axis steps between 0.3 and $0.5 \mu \mathrm{m}$ ), the immunostained somata in the inner nuclear layer (INL), processes in the IPL and somata in the GCL, were further processed using NIH ImageJ Software.

\section{Quantification of contacts}

The percentage fluorescent density of contacts was determined by dividing the fluorescent density of the contacts mask from the green ( $\mathrm{TH}-$ or melanopsin-immunostained somata and processes) mask or red (SRIFimmunostained somata and processes) mask and then multiplied by 100 . To determine the fluorescent density of SRIF amacrine cells, DA amacrine cells, and melanopsin ipRGCs, each of these cells was first masked in $3 \mathrm{D}$ using a custom macro in NIH ImageJ. In the macro, images were resampled to isotropic proportions and features enhanced with a rollingball background subtraction. The green signal $(A)$ was auto thresholded with an isodata threshold, and the red signal $(B)$ was thresholded with an Otsu algorithm. Thresholded signals were then binarized and smoothed by a 3D Gaussian filter with a radius of $165 \mathrm{~nm}$ (contact radius), and the pixel intensity was normalized to a range of 0 to 1 . The contacts mask was produced by $(A \times B)^{C}$, with $C$ serving as a roll-off function to ensure that the value of two pixels separated by the contacting radius would be equal to 0.5 . Empirically, the roll-off function was determined to be 4 . The resulting fluorescent density values are the sum of all intensities of all pixels in that mask.

To estimate the nonspecific contacts between the labeled cells, we calculated the percentage of fluorescent density of contacts after rotating the red mask $90^{\circ}, 180^{\circ}$, and $270^{\circ}$, compared with its original orientation $\left(0^{\circ}\right)$. The percentage fluorescent density of contacts is reported as mean \pm SEM.

\section{Live tissue preparation}

For acutely dissociated retinal cells, isolated retinas were incubated in $\mathrm{Ca}^{2+}$ - and $\mathrm{Mg}^{2+}$-free HBSS (Invitrogen) containing papain (40-45 $\mathrm{U} / \mathrm{ml}, \mathrm{pH} 7.4$; Worthington) for $45 \mathrm{~min}$ at $37^{\circ} \mathrm{C}$. Retinal pieces were transferred to DMEM (Invitrogen) with 10\% fetal bovine serum (Invitrogen), $1 \times$ penicillin-streptomycin-glutamine (Invitrogen), and DNase I ( $100 \mathrm{U} / \mathrm{ml}, \mathrm{pH}$ 7.4; Worthington), and gently triturated to obtain suspensions of isolated cells. Cells were pipetted onto coverslips coated with concanavalin A ( $1 \mathrm{mg} / \mathrm{ml}$; Sigma-Aldrich), and then incubated for $30-60 \mathrm{~min}$ at $37^{\circ} \mathrm{C}$ to allow the cells to adhere to the coverslips. For slices, retinas were isolated and placed GCL down on nitrocellulose paper (Millipore) and cut into $150-200 \mu \mathrm{m}$ slices using a razor blade tissue chopper (Stoelting Tissue Slicer; Stoelting). Slices were rotated $90^{\circ}$ and held in place by two lines of vacuum grease. For whole-retina preparations, retinas were isolated from eyecups and transferred to a glass 
slide. The retina was flat-mounted GCL up and held down at the edges by a nitrocellulose paper ( $47 \mathrm{~mm}$, type TCMF, $0.22 \mu \mathrm{m}$ pores; Millipore) that had been hole punched.

\section{Electrophysiological recordings}

A gravity-fed perfusion system delivered mammalian extracellular solutions to the chamber at $1.3 \mathrm{ml} / \mathrm{min}$. Whole-cell voltage- and currentclamp recordings were made in retinal slices and retinal flat mounts from TH-RFP and OPN4-EGFP mice. Some whole-cell voltage-clamp recordings were made on isolated cells to confirm drug actions under conditions of complete space clamp. Drug responses differed in amplitude in some recordings made from cells in slices compared with isolated cells. The TH-RFP transgenic mouse line was used to identify DA amacrine cells (Zhang et al., 2004). The type 1 DA amacrine cells were identified by their large soma size and wide-field processes in stratum 1 of the IPL (Gustincich et al., 1997; Zhang et al., 2004; Newkirk et al., 2013). To identify M1 ipRGCs in the OPN4-EGFP transgenic mouse line, we used several defining features: (1) dendrites that mono-stratify in stratum 1 of the IPL, (2) bright EGFP fluorescence, (3) resting membrane potential ranging from -55 to $-65 \mathrm{mV}$, and (4) and sharp, robust light response, all of which correspond to previous descriptions of M1 ipRGCs (Schmidt et al., 2008; Schmidt and Kofuji, 2009, 2011).

Labeled cells were identified by epifluorescence using a Zeiss Examiner upright microscope equipped with a $40 \times$ water-immersion objective, 1.2 NA. Drugs were superfused until their actions reached steady state before recording their responses.

To record changes in $\mathrm{K}^{+}$channel currents in DA amacrine cells and M1 ipRGCs, the extracellular bath solution contained the following (in $\mathrm{mm}$ ): $120 \mathrm{NaCl}, 3 \mathrm{KCl}, 1 \mathrm{MgCl}_{2}, 1.2 \mathrm{NaH}_{2} \mathrm{PO}_{4}, 10$ glucose, $2 \mathrm{~mm} \mathrm{CaCl}_{2}$, and $25 \mathrm{NaHCO}_{3}$. $\mathrm{No} \mathrm{Ca}^{2+}$ channel blockers were used to maintain a physiologically normal environment. In addition, the amplitude of $\mathrm{Ca}^{2+}$ channel currents reduced by SRIF and its agonists in $2 \mathrm{~mm}$ external $\mathrm{CaCl}_{2}$ was estimated to be negligible compared with the increase seen in mean $\mathrm{K}^{+}$currents. The intracellular pipette solution contained the following (in mM): $20 \mathrm{KCl}, 120 \mathrm{~K}$-gluconate, $2 \mathrm{MgCl}_{2}, 0.2$ EGTA, $10 \mathrm{HEPES}$, and 2 $\mathrm{Na}_{2}$-ATP. The extracellular bathing solution was bubbled in $95 \% \mathrm{O}_{2}-5 \%$ $\mathrm{CO}_{2}$ at room temperature $\left(21-25^{\circ} \mathrm{C}\right)$. To isolate changes in $\mathrm{Ca}^{2+}$ channel currents, the extracellular solution contained the following (in $\mathrm{mm}$ ): $110 \mathrm{NaCl}, 5 \mathrm{KCl}, 5 \mathrm{CsCl}, 0.1$ 4-aminopyridine, $7.5 \mathrm{BaCl}_{2}, 15$ tetraethylammonium (TEA)-Cl, 10 glucose, and 10 HEPES. The intracellular pipette solution contained the following (in mM): $120 \mathrm{CsMeSO}_{3}, 10$ TEA-Cl, $0.1 \mathrm{CaCl}_{2}, 1$ EGTA, 10 HEPES, 3 ATP-Mg, 0.3 GTP-Li, and 8 phosphocreatine. Tetrodotoxin (TTX; $0.5-1 \mu \mathrm{M}$ ) was added to block $\mathrm{Na}$ channels. A synapse-blocking mixture used to isolate melanopsinbased light responses contained the following: $1 \mathrm{mM} \mathrm{L}-\mathrm{AP}-4,50 \mu \mathrm{M}$ $(2 R)$-amino-5-phosphonovaleric acid (AP-5), $50 \mu \mathrm{M}$ 2,3-dihydroxy-6nitro-7-sulfamoyl-benzo[f] quinoxaline-2,3-dione (NBQX), $100 \mu \mathrm{M}$ picrotoxin, $10 \mu \mathrm{M}$ strychnine, and $50 \mu \mathrm{M}$ 1,2,5,6-tetrahydropyridin-4-yl) methylphosphinic acid (TPMPA). L-AP-4 is an mGluR6 agonist, AP-5 is an NMDA receptor antagonist, NBQX is an AMPA receptor antagonist, picrotoxin and TPMPA are $\mathrm{GABA}_{\mathrm{A}}$ and $\mathrm{GABA}_{\mathrm{C}}$ receptor antagonists, respectively, and strychnine is a glycine receptor antagonist. In the unlikely event that $\mathrm{GABA}_{\mathrm{C}}$ receptor activation might affect ipRGCs, the addition of TPMPA would preclude such an action.

Extracellular solutions were superfused via a fast perfusion system (VC8-S; ALA Scientific). Patch electrodes with 5-10 M $\Omega$ tip resistance were pulled from fire-polished borosilicate glass capillary tubes using a micropipette puller (Sutter Instruments). Cell voltage was clamped with an Axopatch 200B amplifier (Molecular Devices) using whole-cell capacitance and series resistance compensation. Holding potential was set at $-60 \mathrm{mV}$. In voltage-clamp experiments, voltage steps (40 ms) were made in $10 \mathrm{mV}$ increments from -80 to $40 \mathrm{mV}$.

Current-clamp recordings of DA amacrine and M1 ipRGCs were obtained to measure resting potentials and action potential frequency using the same solutions for recording $\mathrm{K}^{+}$currents described above. Hyperpolarizing current was injected in some cells to maintain the membrane potential near $-50 \mathrm{mV}$ for DA amacrine cells and near $-60 \mathrm{mV}$ for M1 ipRGCs. Narrowpass filtered blue light stimuli were delivered via the objective from a shutter- controlled mercury lamp and produced irradiance measured in the recording chamber of $3.4 \times 10^{12}$ photons $/ \mathrm{s} / \mu \mathrm{m}^{2}$ at $480 \mathrm{~nm}$.

All drugs and reagents were prepared in double-distilled water as stock solutions (frozen at $-20^{\circ} \mathrm{C}$ ) or prepared fresh before performing experiments. TTX was purchased from Abcam (ab120055). Somatostatin-14 was obtained from Bachem. L-054,264 (N-[(1R)-2-[[[(1S*,3R*)-3-(aminomethyl)cyclohexyl] methyl]amino]-1-(1 H-indol-3-ylmethyl)-2-oxoethyl]spiro[ $1 H$-indene-1, $4^{\prime}$ piperidine]-1'-carboxamide), L-803,087 ( $N^{2}$-[4-(5,7-difluoro-2-phenyl- $1 \mathrm{H}$ indol-3-yl)-1-oxobutyl]-L-arginine methyl ester trifluoroacetate), and SKF38393 (2,3,4,5-tetrahydro-7,8-dihydroxy-1-phenyl-1 $H$-3-benazepine $\mathrm{HCl})$ were from Tocris Bioscience.

Spontaneous spike activity was quantified for each cell as the average spike rate during $1 \mathrm{~min}$ of recording before and during drug perfusion. The average waveform of the spikes was generated from 20-30 different cells in control or drug preparations. Photocurrent amplitudes were measured from the baseline $(100 \mathrm{~ms})$ before light onset to the peak of the current response. Data analysis for electrophysiology was performed using Clampfit 10 software (Molecular Devices). Graphing and statistical analysis were performed using GraphPad Prism 6.0F software (Graphpad Software). Data are reported as the means \pm SEMs. Values of $p<$ 0.05 were considered statistically significant. All datasets were compared using paired Student's $t$ test.

\section{Results}

The intrinsic light response of M1 ipRGCs is modulated independently by SRIF and DA

In the presence of a pharmacological mixture that blocks synaptic inputs throughout the inner retina, we examined the changes in the intrinsic light response of M1 ipRGCs. The recorded melanopsin ipRGCs shared a morphology similar to that reported for the M1 subtype (Schmidt et al., 2011). The melanopsin-based response to $480 \mathrm{~nm}$ stimulation showed a characteristic inward photocurrent that averaged $85.3 \pm 13.2 \mathrm{pA}$ ( $n=5$ retinas, 25 cells; Fig. 1, black). The photocurrent was suppressed in the presence of the D1 agonist SKF38393 $(5 \mu \mathrm{M}$ ) by $\sim 36 \%$ (control vs SKF, $86.7 \pm 12.3$ vs $55.4 \pm$ $8.1 \mathrm{pA} ; n=4$ retinas, 16 cells; $p=0.0002$; Fig. $1 A$ ), consistent with a previous report (Van Hook et al., 2012).

We found that SRIF (100 nM) also caused a $23 \%$ reduction in the photocurrent (control vs SRIF, 85.2 \pm 13.2 vs $65.8 \pm 12.9 \mathrm{pA}$; $n=4$ retinas, 14 cells; $p=0.0068$; Fig. $1 B$ ). SRIF is reported to inhibit the excitability of RGCs through ion channel modulation mediated by sst ${ }_{4}$ receptors (Farrell et al., 2010, 2014). Therefore, to test whether SRIF directly affects the M1 ipRGC light response, we applied L-803,087 (1 $\mu \mathrm{M})$, an sst $_{4}$ agonist. Application of L-803,087 decreased the photocurrent amplitude by $27 \%$ (control vs L-803,087, $99.3 \pm 16.4$ vs $72.9 \pm 13.9 \mathrm{pA} ; n=3$ retinas, 6 cells; $p=0.0143$; Fig. $1 C$ ). This suggests that SRIF actions occur directly on M1 ipRGCs and that these cells receive inhibitory inputs from both SRIF and DA amacrine cells.

To examine the combined contributions of SRIF and DA on the melanopsin-based photocurrent, we applied SRIF (100 nM) and SKF38393 $(5 \mu \mathrm{M})$ together and L-803,087 $(1 \mu \mathrm{M})$ and SKF38393 $(5 \mu \mathrm{M})$ together. Applying both SRIF and SKF38393 together, as well as L-803,087 and SKF38393 together, caused 21 and 47\% decrease in the photocurrent, respectively (control vs SRIF and SKF38393, $78.5 \pm 17.3$ vs $58.9 \pm 15.9 \mathrm{pA} ; n=4$ retinas, 10 cells; $p=0.0206$; control vs $\mathrm{L}-803,087$ and SKF38393, $107.7 \pm 21.2$ vs $56.8 \pm 13.0 \mathrm{pA} ; n=4$ retinas, 10 cells; $p=0.0371$; Fig. $1 D, E)$. Because there was no additive reduction in the photocurrent when we tested SRIF and SKF38393 together, we next sought evidence for a parallel signaling mechanism by applying L-803,087 with the D1 antagonist SCH23390 $[R(+)$-7-chloro-8hydroxy-3-methyl-1-phenyl-2,3,4,5-tetrahydro- $1 \mathrm{H}$-3-benzazepine hydrochloride]. Application of SCH23390 (5 $\mu \mathrm{M})$ alone did not change the photocurrent amplitude (control vs SCH23390, $80.7 \pm 8.5$ vs $73.8 \pm$ $7.2 \mathrm{pA} ; n=4$ retinas, 11 cells; $p=0.1057$; Fig. $1 F$ ), suggesting that, in 

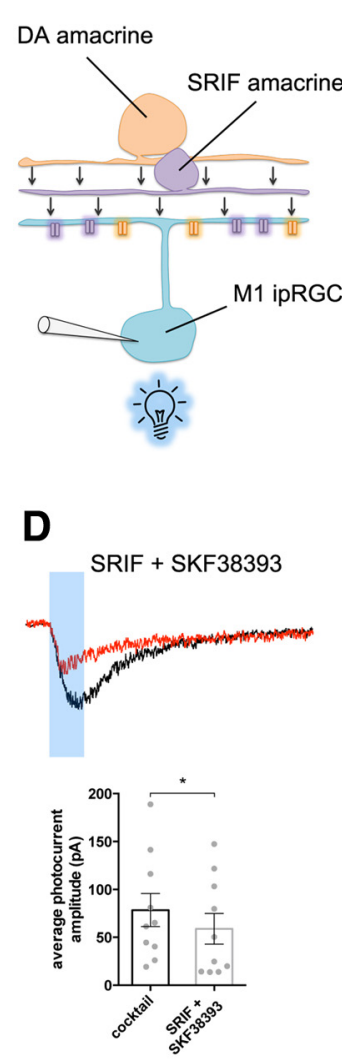
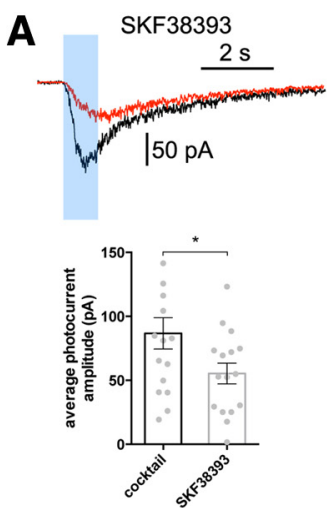

E
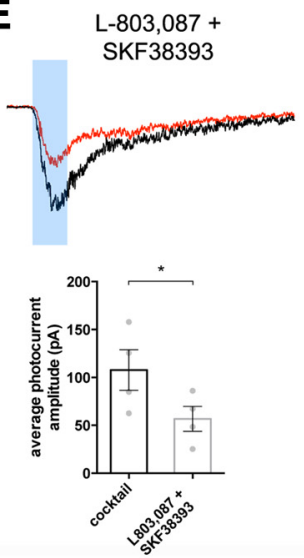

B
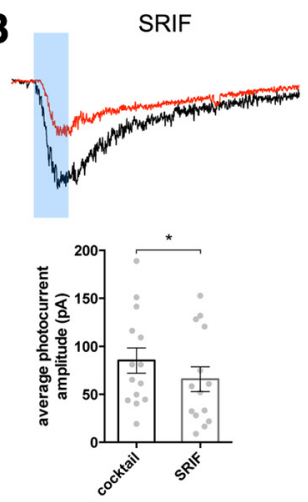

$\mathbf{F}$
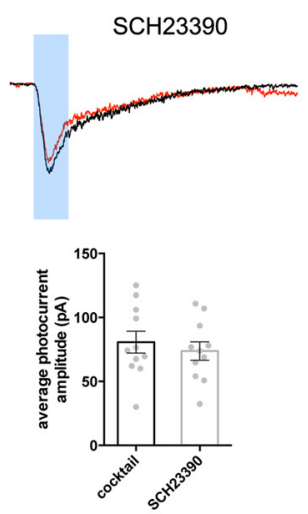
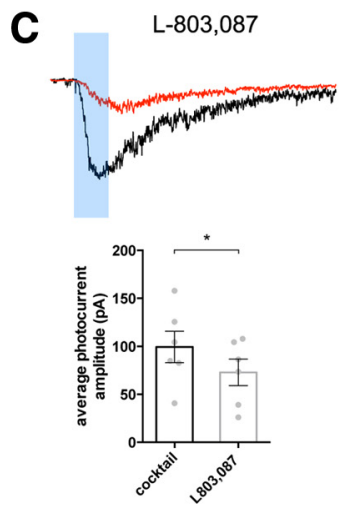

G

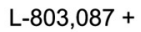
$\mathrm{SCH} 23390$
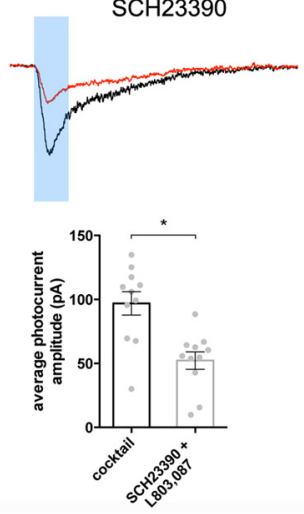

Figure 1. The inhibitory and independent modulatory actions of $S R I F$ and the $D A D_{1}$ receptor agonist $S K F 38393$ on intrinsic melanopsin-based light response in $M 1$ ipRGCS revealed by the selective sst $_{4}$ agonist L-803,087 and the $D_{1}$ receptor antagonist SCH23390. Representative traces of a paired M1 ipRGCs light response in control (synaptic blocking mixture; black) or SKF38393 (5 $\left.\mu \mathrm{M}\right)(\boldsymbol{A})$, SRIF $(100 \mathrm{~nm}(\boldsymbol{B}), \mathrm{L}-803,087(1 \mu \mathrm{M})(\boldsymbol{C}), \operatorname{SRIF}(100 \mathrm{~nm})$ and SKF38393 (5 $\mu \mathrm{M})$ (D), L-803,087 (1 $\mu \mathrm{M})$ and SKF38393 (5 $\mu \mathrm{M})(\boldsymbol{E})$, SCH23390 (5 $\mu \mathrm{M})(\boldsymbol{F})$, or both SCH23390 (5 $\mu \mathrm{M})$ and L-803,087 (1 $\mu \mathrm{M})(\boldsymbol{G})$. Bottom panels in $\boldsymbol{A}-\boldsymbol{G}$ show the average photocurrent amplitudes and significance of photocurrent reduction in the presence drug(s) represented with * $\left.{ }^{*} p<0.05\right)$. Recordings from intact OPN-EGFP flat-mount retinas.

these retinas, there was a low level of basal DA release. However, application of L-803,087 (1 $\mu \mathrm{M})$ and SCH23390 $(5 \mu \mathrm{M})$ together, which isolates SRIF input onto M1 ipRGC, resulted in a $47 \%$ decrease in the photocurrent (control vs L-803,087 and SCH23390, $100.0 \pm 9.2$ vs $52.3 \pm 6.8 \mathrm{pA} ; n=4$ retinas, 11 cells; $p=0.0003$; Fig. $1 G$ ). This suggests that DA and SRIF independently modulate the intrinsic light response of M1 ipRGCs. Photocurrent attenuation was significant in the presence of all drugs individually and in combination, with the exception of $\mathrm{SCH} 23390$ ( $p=0.1057$; Fig. $1 A-G$, graphs).

\section{Contribution of SRIF and L-054,264 (a selective sst ${ }_{2 \mathrm{~A}}$ agonist)} to ion channel modulation in DA amacrine cells

In consideration of the similarly scaled reductions in M1 ipRGC photocurrent amplitude in the presence of SRIF, SKF38393, or both together, we tested whether SRIF modulates DA amacrine cells, which in turn, would feed inhibition onto M1 ipRGCs. To identify the specific changes in DA amacrine cells after SRIF receptor activation, we first applied the endogenous agonist SRIF to isolated DA amacrine cells from TH-RFP retinas or TH-RFP retinal slices. Whole-cell voltageclamp recordings of DA amacrine cells using depolarizing steps produced outward delayed rectifier-like $\mathrm{K}^{+}$currents in control (Fig. $2 A$, left). In the presence of SRIF (100 nM), there was an increase in outward $\mathrm{K}^{+}$currents (Fig. $2 A$, right). We also examined the effects of SRIF on inward $\mathrm{Ca}^{2+}$ channel currents, which were isolated using $\mathrm{K}^{+}$channel blockers and with $\mathrm{Ba}^{2+}$ as a charge carrier. DA amacrine cell $\mathrm{Ca}^{2+}$ channel currents were diminished in the presence of SRIF (Fig. 2C).
The effects of SRIF on $\mathrm{K}^{+}$and $\mathrm{Ca}^{2+}$ channel currents can be seen in the mean current-voltage $(I-V)$ relations (Fig. $2 B, D$ ). SRIF significantly increased $\mathrm{K}^{+}$currents by $39 \%$ (control vs SRIF in slices, $1337.0 \pm 137.2$ vs $1854.0 \pm 106.8 \mathrm{pA} ; n=7$ cells, $p=0.0103$; Fig. $2 B$ ). SRIF significantly decreased $\mathrm{Ca}^{2+}$ channel currents by $35 \%$ (control vs SRIF in slices, $-183.4 \pm$ 24.9 vs $-132.9 \pm 16.1 \mathrm{pA} ; n=6$ cells; in isolated cells, -80.1 vs -48.9 pA; $n=1$ cell; $p=0.0141$; Fig. $2 D)$.

Using the selective sst $_{2 \mathrm{~A}}$ agonist L-054,264, we investigated the effects of activating $\mathrm{sst}_{2 \mathrm{~A}}$ receptors on isolated DA amacrine cells and in retinal slices from TH-RFP mice. Previous immunohistochemical studies have shown that the $s_{2 \mathrm{~A}}$ receptor is localized to DA amacrine cells (Johnson et al., 1998, 1999, 2000). Peak $\mathrm{K}^{+}$currents at $40 \mathrm{mV}$ increased $34 \%$ when L-054,264 (1 $\mu \mathrm{M})$ was applied (Fig. $3 A$ ), as also seen in the mean $I-V$ relation of $\mathrm{K}^{+}$currents (control vs L-054,264 in slices, $1331 \pm 100.6$ vs $1782 \pm 30.4 \mathrm{pA} ; n=5$ cells; $p=0.0265$ Fig. $3 B$ ). We also examined inward $\mathrm{Ca}^{2+}$ channel currents in the absence and presence of L-054,264 (Fig. 3C). Average peak inward $\mathrm{Ca}^{2+}$ channel currents showed a significant reduction (25\%) with L-054,264 compared with the control recordings (control vs L-054,264 in slices, $-187.6 \pm 18.0$ vs $-140.4 \pm$ $21.77 \mathrm{pA} ; n=6$ cells; $p=0.0092$; Fig. $3 D$ ). These results suggest that SRIF acts on $\mathrm{sst}_{2 \mathrm{~A}}$ receptors in DA amacrine cells to modulate ion channel activity that promotes inhibition of DA amacrine cells, making it unlikely that SRIF amacrine cells inhibit ipRGCs via intermediary DA amacrine cells. 
A

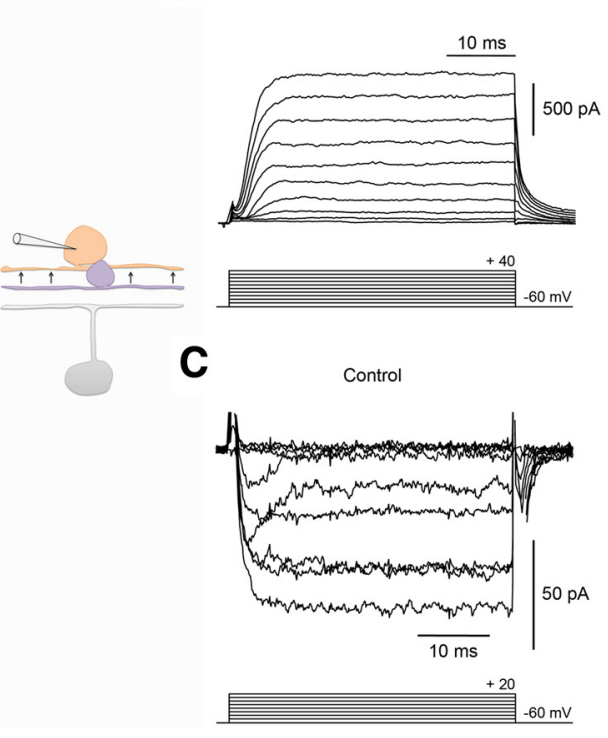

SRIF

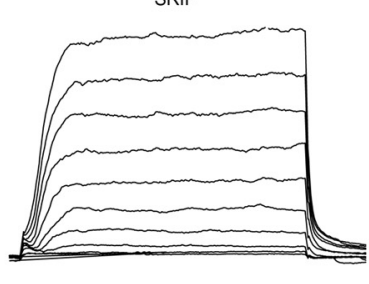

SRIF

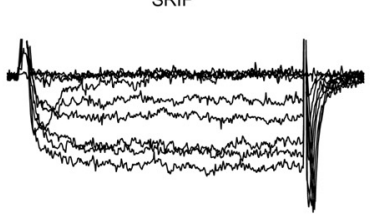

B

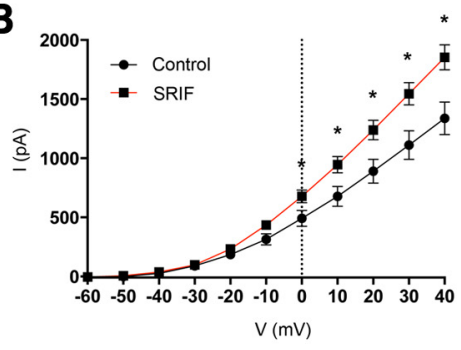

D

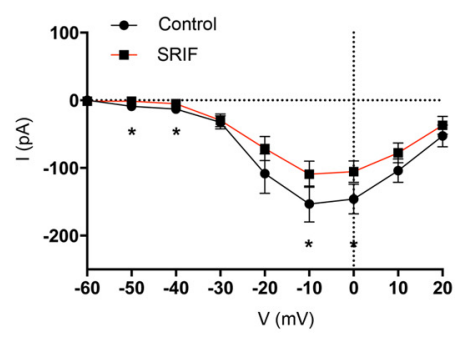

Figure 2. Modulation by SRIF of $\mathrm{K}^{+}$and $\mathrm{Ca}^{2+}$ channel currents on DA amacrine cells in TH-RFP retinal slices and isolated RFP cells. $A$, Outward $I_{\mathrm{K}}$ recording from a DA amacrine cell in a retinal slice in the absence (left) and presence (right) of SRIF peptide (100 nM). $B$, Mean $I-V$ relationships for $I_{K}$ recorded in retinal slices in the absence (black) and presence (red) of SRIF. $C$, Inward $I_{C a}$ in the absence (left) and presence (right) of SRIF recorded in an isolated cell. $\boldsymbol{D}$, Mean $I-V$ relationships for $I_{\text {Ca }}$ pooled from slices and isolated cells in the absence (black) and presence (red) of SRIF. Recordings were made in the presence of TTX (500 nM). Voltage command protocol is shown below the current trace. $n=7$ cells per group. ${ }^{*} p<0.05$.

A
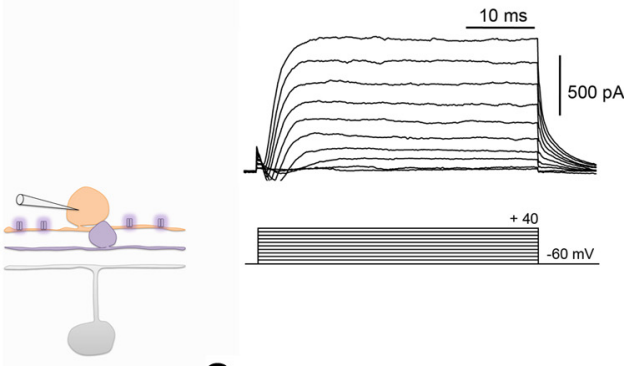

C
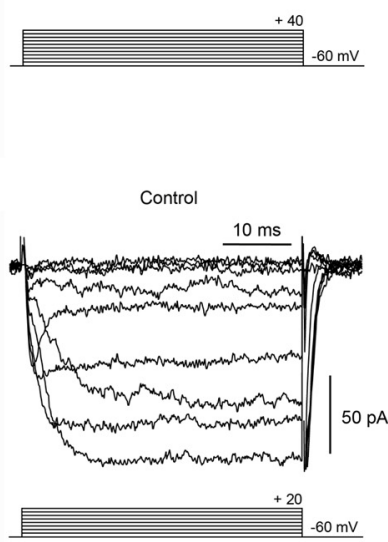
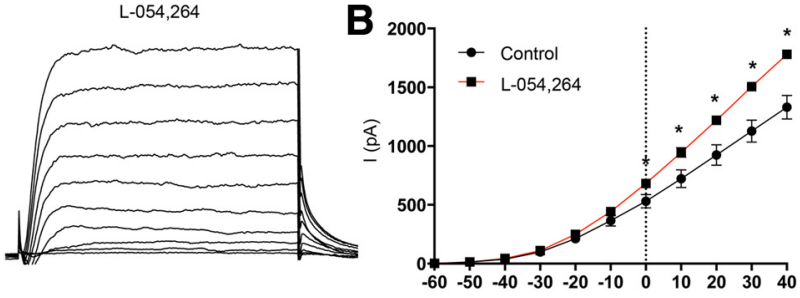

$\mathrm{V}(\mathrm{mV})$

D
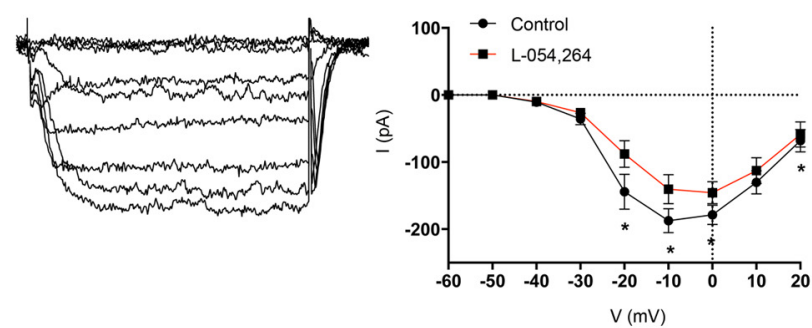

Figure 3. Effects of $\mathrm{L}-054,264$, a selective $\mathrm{sst}_{2 \mathrm{~A}}$ agonist, on $\mathrm{K}^{+}$and $\mathrm{Ca}^{2+}$ channel currents in DA amacrine cells in TH-RFP retinal slices. $A$, Outward $I_{\mathrm{K}}$ recording from a DA amacrine cell in the absence (left) and presence (right) of L-054,264 (1 $\mu \mathrm{M})$. B, Mean $/-V$ relationships for $I_{K}$ in the absence (black) and presence (red) of L-054,264. $C$, Inward $I_{C a}$ in the absence (left) and presence (right) of L-054,264. D, Mean I-V relationships for $I_{\mathrm{Ca}}$ in the absence (black) and presence (red) of L-054,264. Recordings were made in the presence of TTX ( $500 \mathrm{~nm}$ ). Voltage command protocol is shown below the current trace. $n=5-6$ cells per group. ${ }^{*} p<0.05$.

\section{Effects of SRIF and sst ${ }_{2 \mathrm{~A}}$ agonist on action potential} generation in DA amacrine cells

DA amacrine cells generate action potentials spontaneously, and these spikes are thought to trigger DA release (White, 1996). Therefore, in consideration of our previous finding that SRIF modulates ion channels in DA amacrine cells, we examined whether SRIF changes the firing properties of DA amacrine cells. In current-clamp recordings, DA amacrine cells in retinal slices produced tonic spiking activity and had an average membrane potential of $-55 \pm 1.15 \mathrm{mV}$ (without current injection; $n=28$ cells), which was similar to previous findings (Newkirk et al., 2013). Application of SRIF reduced the number of spikes, slightly hyperpolarized the cells, and revealed the presence of small transient depolarizations (Fig. $4 A$, red). The average spike waveform did not change (Fig. $4 C$, red), and the average peak amplitude and half-width showed no significant alterations (Fig. $4 D, E$ ). However, quantitative analysis of DA amacrine spike rates revealed a significant in- 

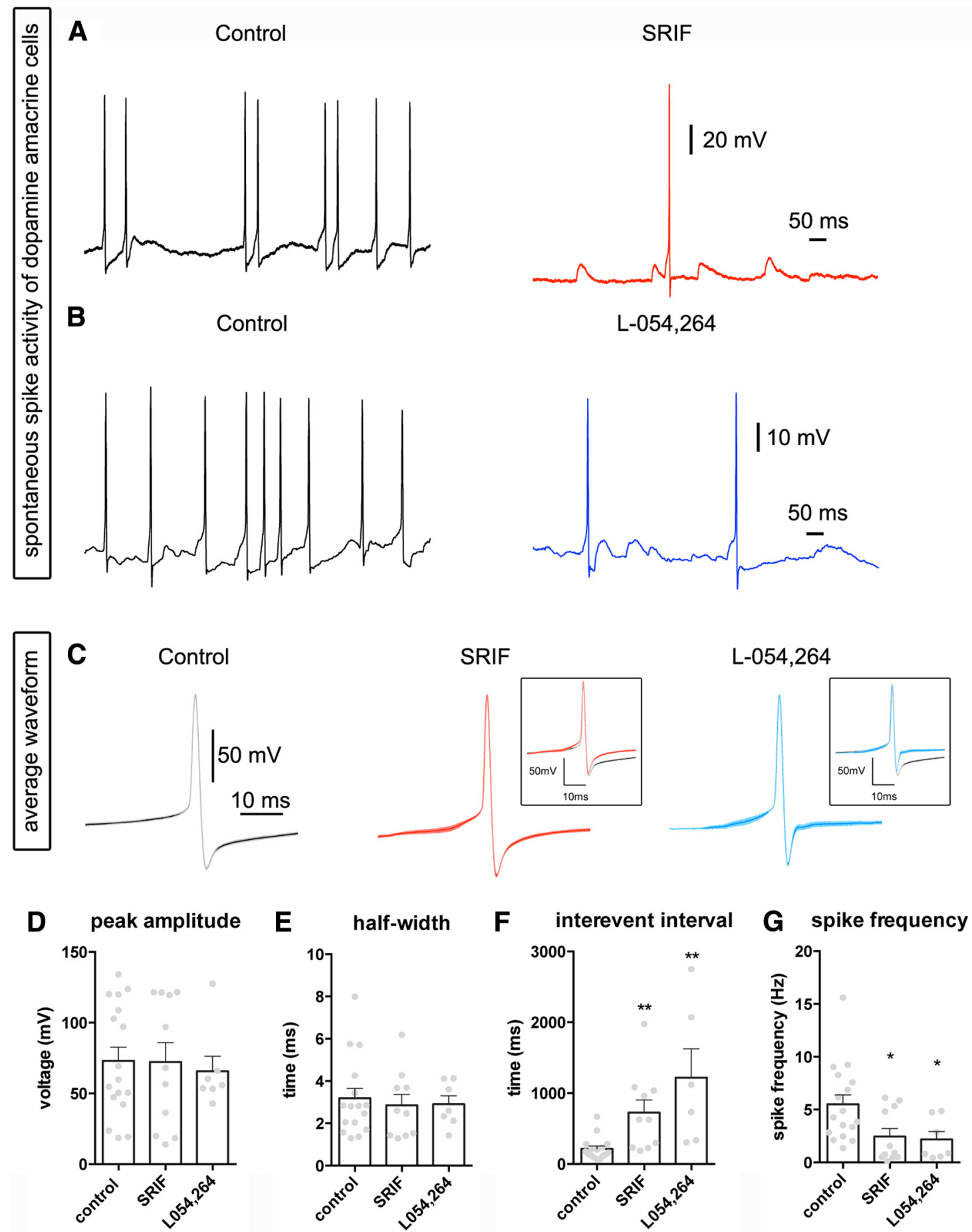

Figure 4. SRIF and L-054,264 decrease spontaneous spiking in DA amacrine cells from TH-RFP slices. A, An example trace of spontaneous spiking from a DA amacrine cell in the control (left) and SRIF (100 nm; right). B, Spontaneous spike activity from a DA amacrine cell in absence (left) and presence (right) of L054,264 (1 $\mu \mathrm{M})$. C, Average waveform of spikes in control (gray), SRIF (red), and L054,264 (blue). Insets show overlay of average spike waveforms in control with SRIF or L-054,264. There was no significant difference in the peak amplitude $(\boldsymbol{D})$ or half-width $(\boldsymbol{E})$ in the spikes from DA amacrine cells when treated with SRIF or L-054,264. Quantification of interevent intervals $(\boldsymbol{F})$ and spike frequency $(\boldsymbol{G})$ in control compared with SRIF or L-054,264 revealed a significant difference and opposite trends. ${ }^{*} p<0.05$.

crease in the average interevent interval (from 190.2 to 685.8 ms; $n=5$ retinas, 10 cells; $p<0.01$; Fig. $4 F)$, and the spike frequency was greatly reduced $(6.1$ to $2.6 \mathrm{~Hz} ; n=5$ retinas, 11 cells; $p<0.05$; Fig. $4 G$ ).

To determine whether the effects of SRIF on resting membrane properties of DA amacrine cells were mediated by $s_{2} t_{2 \mathrm{~A}}$ receptors, we applied L-054,264 onto current-clamped DA amacrine cells in retinal slices. L-054,264 reduced the number of spikes compared with control (Fig. 4B) and did not significantly change the average waveform, peak amplitude, or halfwidth (Fig. 4C-E). As was the case with SRIF, L-054,264 significantly increased the interval between spikes (253.9 to $1203 \mathrm{~ms} ; n=3$ retinas, 7 cells; $p<0.05)$ and decreased spike frequency ( 5.2 to $2.3 \mathrm{~Hz} ; n=3$ retinas, 7 cells; $p<0.01$; Fig. 

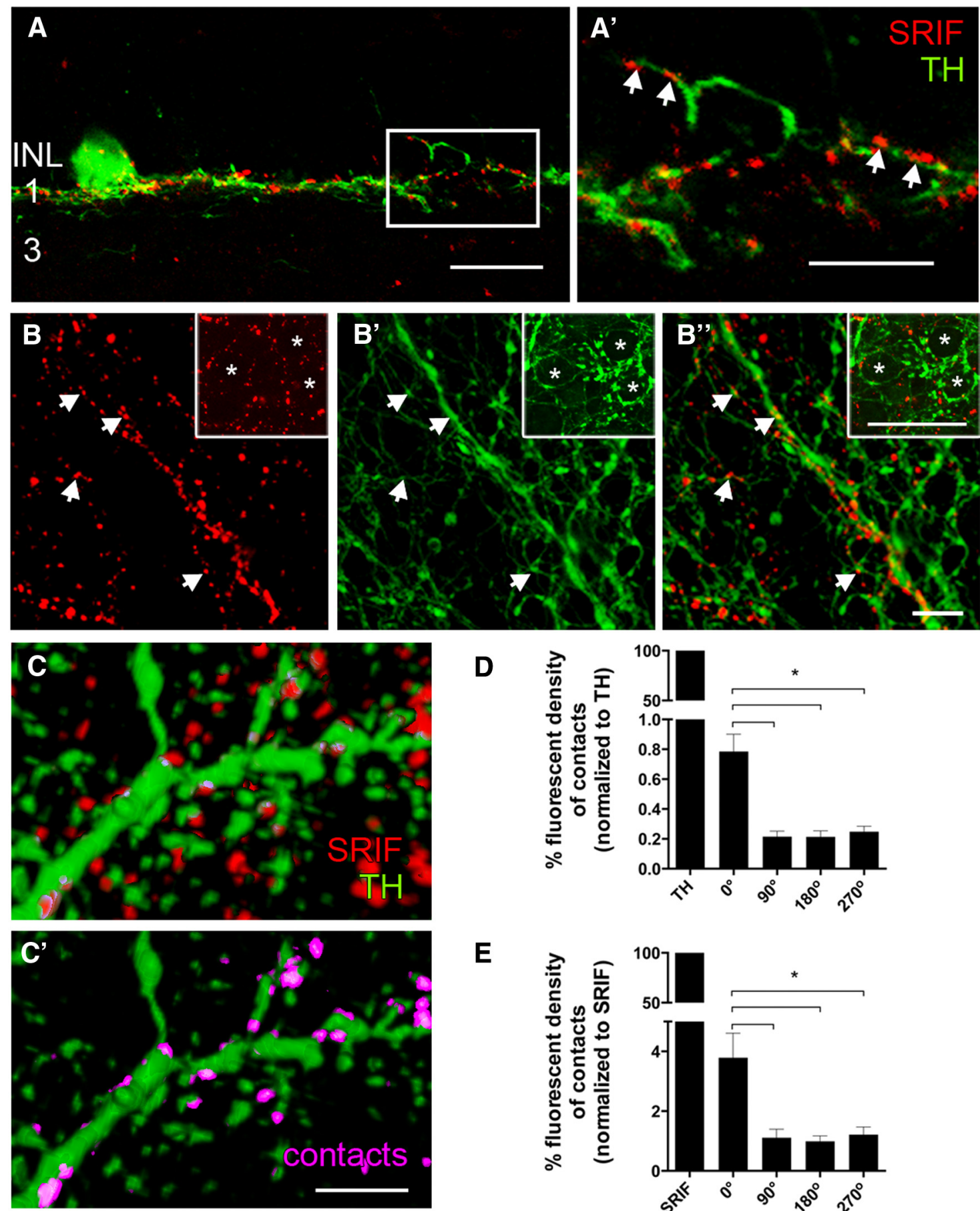

$\mathbf{E}$

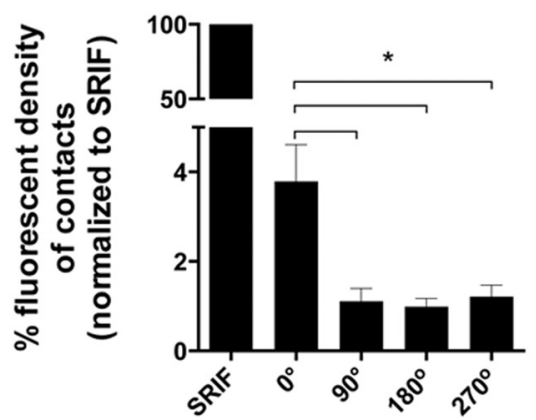

Figure 5. SRIF and TH immunostaining show closely apposed SRIF- and TH-immunoreactive amacrine cell processes in stratum 1 of the IPL. $A$, SRIF amacrine cell processes (red) and TH-immunoreactive DA amacrine cell processes (green) are in close proximity in stratum 1 of the IPL. $\boldsymbol{A}^{\prime}, \mathrm{A} 3 \times$ magnification of the box in $\boldsymbol{A}$ reveals multiple contacts between SRIF amacrine cell and DA amacrine cell processes in stratum 1 of the IPL. Whole-mount retina shows varicose and fine SRIF amacrine cell processes $(\boldsymbol{B})$ and large- and fine-caliber DA amacrine cell processes $\left(\boldsymbol{B}^{\prime}\right)$. $\boldsymbol{B}^{\prime \prime}$, Merged images highlight the juxtaposition of the SRIF amacrine and DA amacrine cell processes. Contacts are more frequent near the varicosities of the DA amacrine cell processes. Arrows show the points of contacts between SRIF and DA amacrine cell processes. Insets show perisomatic rings formed by SRIF and TH immunoreactivity. Asterisks mark the cell bodies that are surrounded by SRIF and DA amacrine cell processes. C, A 3D model of SRIF and DA amacrine cells from an image stack taken through the IPL of a retinal whole mount was generated to determine contacts between the processes. $C^{\prime}, 0$ mitting the red channel reveals SRIF-immunoreactive processes and puncta that make contact with DA amacrine cell processes. Pink labeling shows contacts between SRIF and DA amacrine cell processes. D, Quantification of fluorescent density created from the contacting processes was normalized to the fluorescent density of the TH immunoreactivity. Rotated reconstructions $\left(90^{\circ}, 180^{\circ}\right.$, and $\left.270^{\circ}\right)$ had significantly less fluorescent density generated from the contacting processes. $\boldsymbol{E}$, Fluorescent density of the contacts was also normalized to the fluorescent density of SRIF immunoreactivity. Fluorescent density of contacts after rotation was significantly less than the unrotated image. Scale bars: $A, 20 \mu \mathrm{m} ; \boldsymbol{A}^{\prime}, \boldsymbol{B}, \boldsymbol{C}, 10 \mu \mathrm{m} .{ }^{*} p<0.05$. 

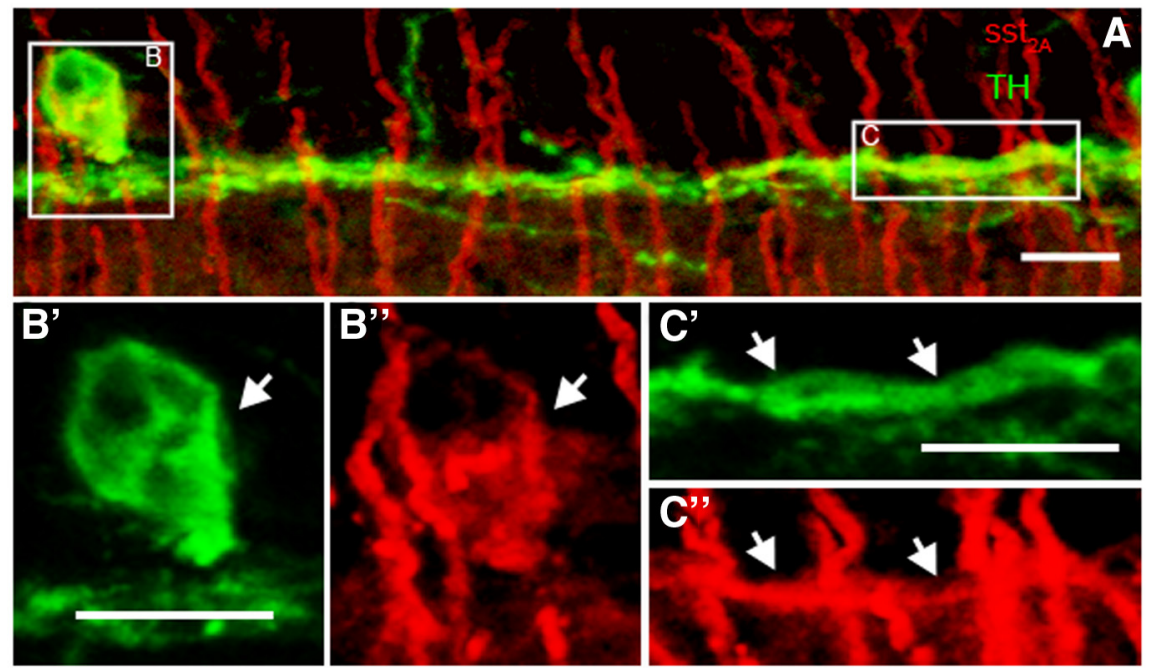

Figure 6. $s \mathrm{st}_{2 \mathrm{~A}}$ immunoreactivity is colocalized with TH immunoreactivity in a retinal section. $A$, Merged image of $\mathrm{sst}_{2 \mathrm{~A}}$ immunoreactivity (red) and TH immunoreactivity (green) shows $s_{2 A}$ strongly immunostained rod bipolar cell axons and is colocalized with a TH-immunoreactive amacrine cell somata $(\boldsymbol{B})$ that is located in the proximal INL and processes $(\boldsymbol{C})$ that primarily ramify in stratum 1 of the IPL. $\boldsymbol{B}^{\prime}$, TH immunoreactivity robustly labels DA amacrine cell somata in the INL. $\boldsymbol{B}^{\prime \prime}$, sst $_{2 A}$ immunoreactivity labels the same DA amacrine cell soma. $\boldsymbol{C}^{\prime}$, TH-immunoreactive processes ramify in stratum 1 of the IPL. $\boldsymbol{C}^{\prime}$, sst $_{2 A}$ immunoreactivity is found in DA amacrine cell processes in stratum 1 of the IPL. Arrows highlight the colocalized soma and process of sst $2 \mathrm{~A}$ and TH immunoreactivity. Scale bars, $10 \mu \mathrm{m}$.

$4 F, G)$. These results suggest that SRIF, acting through $s_{2} t_{2 \mathrm{~A}}$ receptors, can strongly inhibit the spontaneous activity of DA amacrine cells, an action that could downregulate DA release, and feedback inhibition onto M1 ipRGCs.

\section{Fasciculation of SRIF and TH processes in stratum 1 of the IPL}

To establish an anatomical basis for this synaptic interaction, we sought next to determine the relationship between SRIF amacrine cells and the TH-immunoreactive DA amacrine cells and their processes in stratum 1 of the IPL. Rarely occurring SRIF-immunoreactive amacrine cell somata were located in the INL and displaced to the GCL. Their processes, characterized by multiple varicosities, formed a continuous network in stratum 1 of the IPL (Fig. 5A, red), and a few processes were in strata 3 and 5 of the IPL. THimmunoreactive amacrine cell somata and processes were located in the INL, and their processes primarily ramified in stratum 1 of the IPL ( $n=9$ retinas; Fig. $5 A$, green). A few processes were also found in stratum 3 of the IPL, and some processes crossed the INL and ramified in the OPL (data not shown). Retinal sections double labeled with SRIF and TH antibodies showed that the SRIF- and TH-immunoreactive processes were in close proximity in stratum 1 of the IPL with numerous contacts between these processes (Fig. $5 A, A^{\prime}$, arrows). In addition, SRIF-immunoreactive processes contacted $\mathrm{TH}$-immunoreactive somata, and few SRIF- and TH-immunoreactive processes were in very close proximity and formed contacts in stratum 3 of the IPL (Fig. 5A). The SRIF- and TH-immunoreactive processes in stratum 1 of the IPL were closely aligned in whole-mounted retinas (Fig. $5 B^{\prime \prime}$ ) and were characterized by the juxtaposition of SRIFimmunoreactive processes $(n=9$ retinas; Fig. $5 B)$ to both fine- and large-diameter TH processes (Fig. $5 B^{\prime}$ ) in all retinal regions. Notably, the fascicles of SRIF- and TH-immunoreactive processes formed ringlike patterns around the AII cell bodies (Fig. 5B, insets; Voigt and Wässle, 1987; Contini and Raviola, 2003; Debertin et al., 2015).
To test whether the contacts between the SRIF- and TH-immunoreactive processes were nonrandom, we quantified the fluorescent density of contacts between SRIF- and $\mathrm{TH}$-immunoreactive processes in a $3 \mathrm{D}$ reconstruction of an image stack taken through the IPL (Fig. 5C,C'; see Materials and Methods, Quantification of contacts). SRIF- and TH-immunoreactive processes made significantly more contacts in the original $\left(0^{\circ}\right)$ image reconstruction compared with each of the rotated $\left(90^{\circ}, 180^{\circ}\right.$, and $\left.270^{\circ}\right)$ image reconstructions $(n=6$ retinas; $p<0.01,0.02$, and 0.01 , respectively). The decrease in percentage fluorescent density of contacts on rotation was present when normalized to $\mathrm{TH}(0.79 \pm 0.11 \%$ at $0^{\circ}, 0.21 \pm 0.04 \%$ at $90^{\circ}, 0.21 \pm 0.04 \%$ at $180^{\circ}$, and $0.25 \pm 0.04 \%$ at $270^{\circ} ; n=6$ retinas) or SRIF fluorescent density (3.80 \pm $0.82 \%$ at $0^{\circ}, 1.11 \pm 0.29 \%$ at $90^{\circ}, 0.99 \pm$ $0.18 \%$ at $180^{\circ}$, and $1.21 \pm 0.26 \%$ at $270^{\circ}$; $n=6$ retinas; Fig. $5 D, E)$. Collectively, SRIF and DA amacrine cell processes extensively fasciculate in stratum 1 throughout the entire retina, and their processes have numerous contacts that are likely to be sites for neurotransmission and cell modulation.

\section{sst $_{2 \mathrm{~A}}$ localization at DA amacrine cell somata and their processes}

To establish $\mathrm{sst}_{2 \mathrm{~A}}$ receptor expression by DA amacrine cells, retinal sections were double immunolabeled with $\mathrm{sst}_{2 \mathrm{~A}}$ and $\mathrm{TH}$ antibodies. Consistent with previous studies, $\mathrm{sst}_{2 \mathrm{~A}}$ immunoreactivity was found in rod bipolar cells, including their dendrites, axon, and axonal terminals ( $n=5$ retinas; Fig. $6 A$; Johnson et al., 2000). Although the intense rod bipolar cell labeling obscures many of the DA amacrine cell processes, double immunolabeling showed that $\mathrm{sst}_{2 \mathrm{~A}}$ immunoreactivity was localized to $\mathrm{TH}$-immunoreactive amacrine cell somata located in the INL adjacent to the IPL (Fig. $6 B-B^{\prime \prime}$ ) and their processes in stratum 1 of the IPL (Johnson et al., 1998, 1999, 2000; Fig. $6 C-C^{\prime \prime}$ ). These results confirm that DA amacrine cells express the SRIF receptor subtype $s_{2 \mathrm{~A}}$ on their soma in the INL and processes in stratum 1 of IPL.

\section{Modulation of $\mathrm{K}^{+}$and $\mathrm{Ca}^{2+}$ channels in M1 ipRGCs by SRIF and the sst ${ }_{4}$ agonist L-803,087}

In view of the effect of SRIF on M1 ipRGC light responses, we examined the SRIF receptor activation on $\mathrm{K}^{+}$and $\mathrm{Ca}^{2+}$ channel currents in M1 ipRGCs in OPN4-EGFP retinas. We first performed wholecell voltage clamp on EGFP fluorescent cells in the presence and absence of SRIF. Voltage-clamped EGFP fluorescent cells showed a $37 \%$ increase in peak outward $\mathrm{K}^{+}$currents at $40 \mathrm{mV}$ when SRIF $(100$ $\mathrm{nM}$ ) was applied (Fig. $7 A$, right) compared with control (Fig. $7 A$, left). This effect of SRIF is shown in mean $I-V$ relations (control vs SRIF in slices, $648.2 \pm 114.9$ vs $1031.0 \pm 161.9 \mathrm{pA} ; n=9$ cells; $p=$ 0.0095; Fig. 7B). In addition, EGFP fluorescent cells showed smaller inward $\mathrm{Ca}^{2+}$ channel currents during application of SRIF (Fig. 7C, right) compared with control (Fig. 7C, left). There was a $39 \%$ attenuation of peak inward $\mathrm{Ca}^{2+}$ channel current (control vs SRIF in slices, $-111.0 \pm 26.3$ vs $-49.0 \pm 36.7 \mathrm{pA} ; n=2$ cells; in isolated cells, $-72.8 \pm 13.9$ vs $-44.0 \pm 7.7 \mathrm{pA} ; n=6$ cells; $p=0.0163$; Fig. 7D). 
A

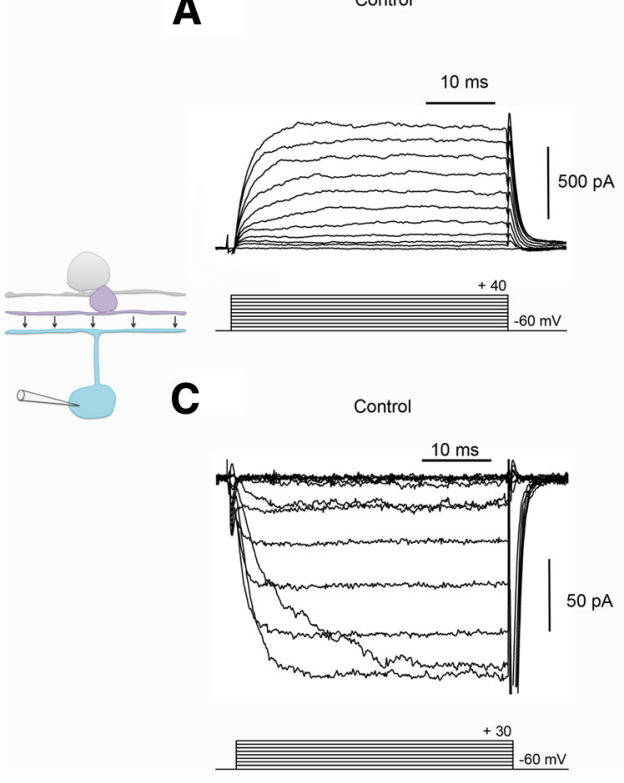

SRIF
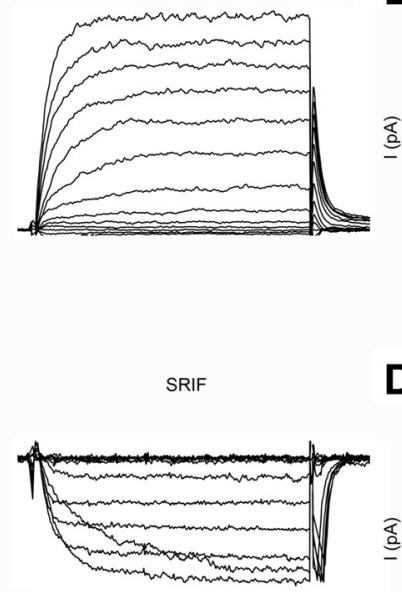

B

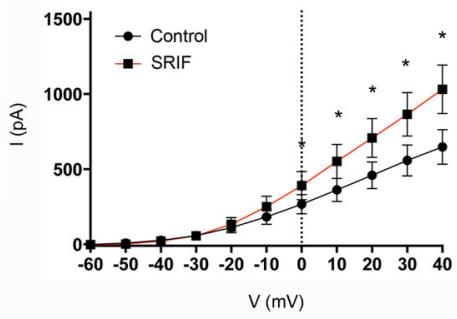

D

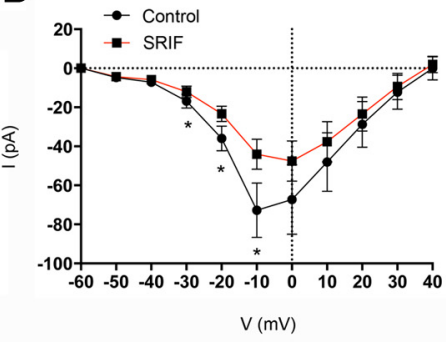

Figure 7. SRIF modulation of $\mathrm{K}^{+}$and $\mathrm{Ca}^{2+}$ channel currents in M1 ipRGCs from OPN-EGFP retinas. $A$, Outward $I_{\mathrm{K}}$ recording from an M1 ipRGC in a retinal slice in the absence (left) and presence (right) of SRIF (100 nM). $\boldsymbol{B}$, Mean I-V relationships for $I_{K}$ from recordings in slices in the absence (black) and presence (red) of SRIF. $C, I_{C a}$ recording in an isolated EGFP cell in the absence (left) and presence (right) of SRIF. D, Mean I-V relationships for I ca pooled from slices and isolated cells in the absence (black) and presence (red) of SRIF. Recordings were made in the presence of TTX ( $500 \mathrm{nm)}$ ). Voltage command protocol is shown below the current trace. $n=8-9$ cells per group. ${ }^{*} p<0.05$.

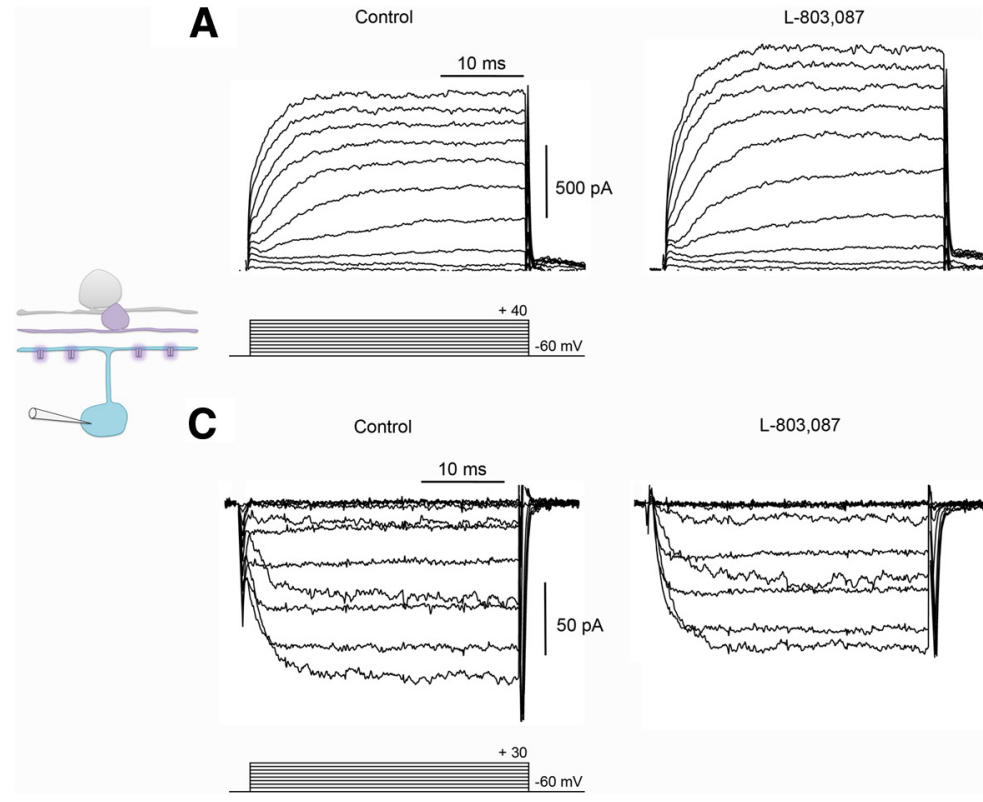

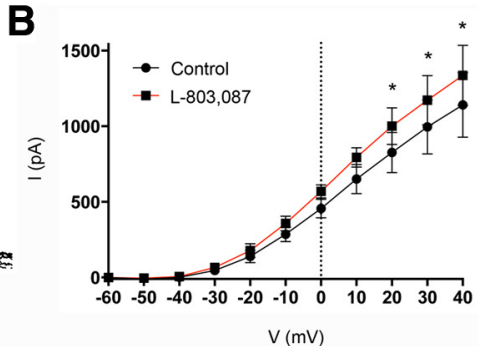

D

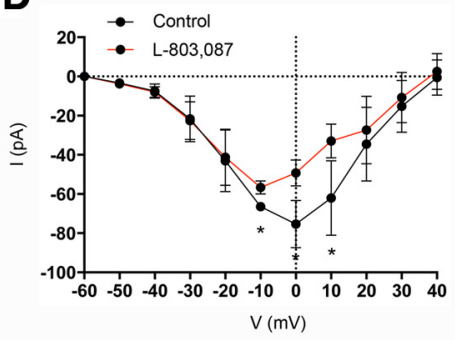

Figure 8. The selective sst ${ }_{4}$ agonist L-803,087 modulated $\mathrm{K}^{+}$and $\mathrm{Ca}^{2+}$ channel currents in M1 ipRGCs from OPN4 -EGFP retinas. $A, 0$ utward $I_{\mathrm{K}}$ recording from an M1 ipRGC in a retinal slice in the absence (left) and presence (right) of L-803,087 $(1 \mu \mathrm{M})$. B, Mean $I-V$ relationships for $I_{K}$ from recordings in slices in the absence (black) and presence (red) of $\mathrm{L}-803,087$. $\boldsymbol{C}$, $I_{\text {Ca }}$ recording in an isolated OPN4 -EGFP cell in the absence (left) and presence (right) of L-803,087. D, Mean $I-V$ relationships for $I_{\text {Ca }}$ pooled from slices and isolated cells in the absence (black) and presence (red) of L-803,087. Recordings were made in the presence of TTX (500 nM). Voltage command protocol is seen below the current trace. $n=4-5$ cells per group. ${ }^{*} p<0.05$.

Similarly, when we tested for the effects of the selective sst ${ }_{4}$ agonist L-803,087, on M1 ipRGCs, they produced (Fig. 8A, left) outward $\mathrm{K}^{+}$currents that were potentiated in the presence of L-803,087 ( $1 \mu \mathrm{M}$; Fig. $8 A$, right). The changes in $\mathrm{K}^{+}$currents with the application of L-803,087 can be seen in the mean $I-V$ relations (control vs L-803,087 in slices, $1141 \pm 212.8$ vs $1336 \pm 199.6 \mathrm{pA} ; n=4$ cells; $p=$ 0.0064; Fig. $8 B$ ). In addition, M1 ipRGCs displayed a reduction in $\mathrm{Ca}^{2+}$ channel currents when we compared control recordings (Fig. $8 C$, left) with those made with the application of L-803,087 (Fig. 8C, right). This is shown in the mean $I-V$ relations in Figure $8 \mathrm{D}$ (control vs L-803,087 in slices, $-74.9 \pm 23.9$ vs $-33.11 \pm 20.3 \mathrm{pA} ; n=2$ cells; in isolated cells, $-75.3 \pm 12.1 \mathrm{vs}-62.5 \pm 9.0 \mathrm{pA} ; n=3$ cells; $p=$ $0.0343)$. Thus, SRIF acting via $s t_{4}$ receptors modulates $\mathrm{K}^{+}$and $\mathrm{Ca}^{2+}$ ion channels in M1 ipRGCs.

\section{Effects of SRIF and L-803,087 on M1 ipRGC excitability}

At rest, the EGFP-labeled ipRGCs from which we recorded in retinal slices had a resting membrane potential of $-63 \pm 1.7 \mathrm{mV}$ 
A Control

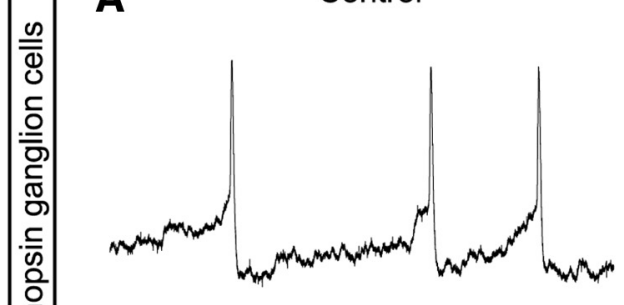

B

Control

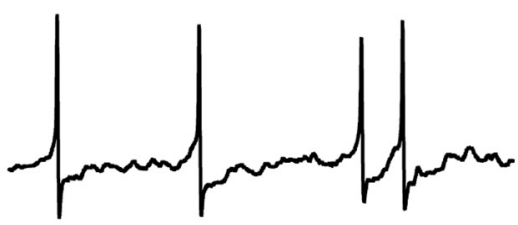

SRIF

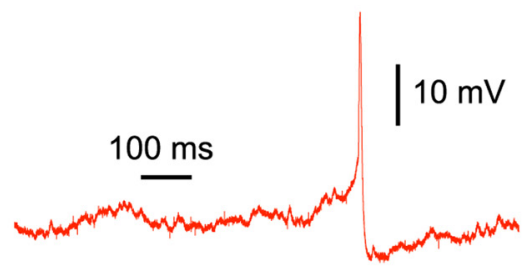

L-803, 087

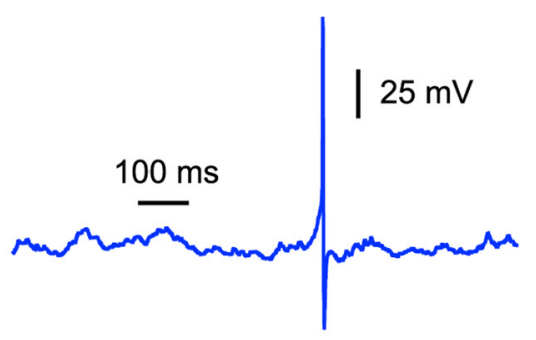

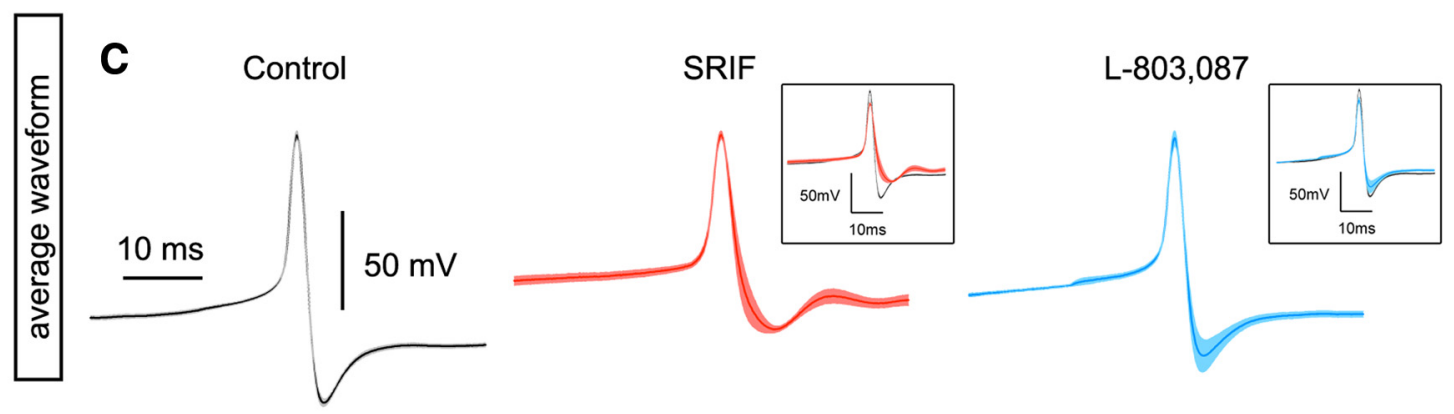
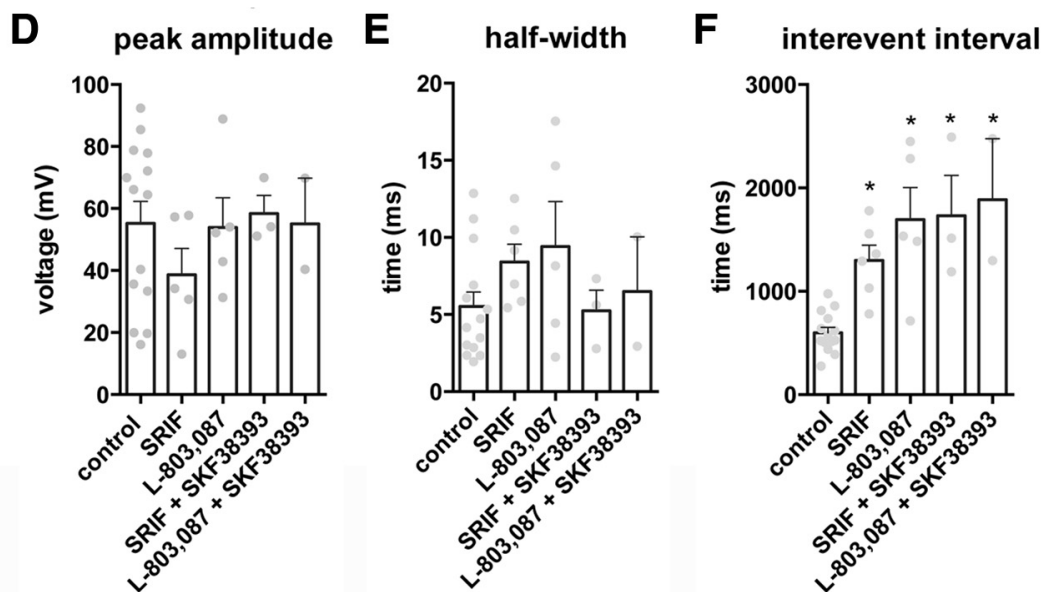

G spike frequency

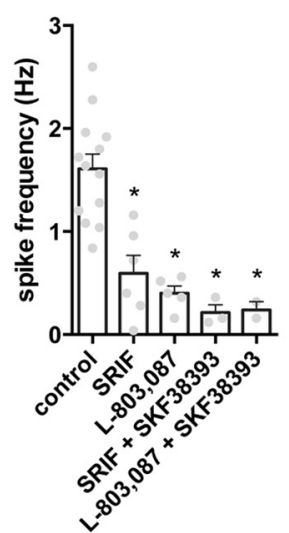

Figure 9. Spontaneous spike activity in M1 ipRGCs from OPN-EGFP retinal slices was modulated by SRIF and L-803,087. A, Representative trace of spontaneous spiking activity of a M1 ipRGC without (left) and with (right) the application of SRIF (100 nM). B, An example of a spontaneously spiking M1 ipRGC in absence (left) and presence (right) of L-803,087 (1 $\mu \mathrm{M})$. C, The average waveform of spikes from M1 ipRGCs in control (gray), SRIF (red), and L-803,087 (blue). Insets show overlay of average waveforms in control with SRIF or L-803,087. Quantitative analysis of peak amplitude $(\boldsymbol{D})$ and half-width $(\boldsymbol{E})$ of spikes from M1 ipRGCs show no significant differences in the presence of SRIF or L-803,087. The interevent intervals $(\boldsymbol{F})$ and spike frequency $(\boldsymbol{G})$ significantly increased and decreased, respectively, in the presence of SRIF, L-803,087, and in combination with the $\mathrm{D}_{1}$ agonist SKF38393 $(5 \mu \mathrm{M}) .{ }^{*} p<0.05$.

( $n=30$ cells), similar to that reported for M1 ipRGCs (Zhao et al., 2014). The recorded M1 ipRGCs exhibited an intrinsic spontaneous firing rate of $1.5 \pm 0.16 \mathrm{~Hz}(n=30$ cells). Currentclamped M1 ipRGCs fired spontaneously at rates that decreased during application of SRIF (Fig. 9A, black vs red). The averaged waveform was altered in the presence of SRIF, with a slight reduction in spike amplitude and a small increase after hyperpolarization (Fig. $9 C$, red). Quantification of the average peak amplitude of spikes in the presence of SRIF revealed a nonsignificant trend toward reduction (Fig. 9D). Analysis of spike half-widths in control or in the 
presence of SRIF also showed no significant differences (Fig. 9E). However, SRIF significantly increased the interevent interval between spikes (501 to $1300 \mathrm{~ms}$ ), dramatically reducing the spike frequency in M1 ipRGCs (1.9 to $0.6 \mathrm{~Hz}$; Fig. $9 F, G$ ).

We next examined whether the actions of SRIF in regulating the resting properties of $\mathrm{M} 1 \mathrm{ipRGCs}$ were mediated through $\mathrm{sst}_{4}$ receptors. In the presence of L-803,087, M1 ipRGCs in retinal slices displayed a decrease in the number of spikes and a larger, more transient spike (Fig. 9B). However, there was no significant change in the average waveform, peak amplitude, and half-width (Fig. 9C, blue, $D, E)$. Nevertheless, M1 ipRGCs showed the characteristic effects of SRIF on spontaneous activity, which include an increased interevent interval (675 to $1693 \mathrm{~ms}$ ) and decreased spike frequency (1.6 to $0.6 \mathrm{~Hz}$ ) during application of L-803,087 (Fig. 9 F, $G$ ).

Next we addressed changes in the resting properties in M1 ipRGCs in the presence of SRIF and DA amacrine cell input. We tested changes in spike properties in the presence of SRIF and the D1 agonist SKF38393, as well as L-803,087 and SKF38393. There were no significant changes in the peak amplitude and half-width (Fig. $9 D, E)$. The interval between spikes increased and the spike frequency decreased compared with control (Fig. $9 F, G$ ). There was no significant additive effect of SKF38393 on the actions of SRIF or L-803,087 (Fig. 9F, G). Together, these results suggest that SRIF acts via the $\mathrm{sst}_{4}$ receptor to directly regulate $\mathrm{M} 1 \mathrm{ipRGC}$ resting properties, and this action is unaffected by DA amacrine cell input.

\section{Contacts of SRIF processes and M1 ipRGC dendrites in stratum 1 of IPL}

To test whether SRIF amacrine cell processes formed contacts with M1 ipRGC dendrites, we examined the distribution of SRIF amacrine cells and melanopsin-immunoreactive M1 ipRGCs in both retinal sections and whole mounts. Melanopsin immunoreactivity was localized to a small number of somata in the GCL ( $n=4$ retinas; Fig. $10 A$, green, asterisk) and in the proximal INL (data not shown) and to dendrites in strata 1 and 5 of the IPL (Fig. $10 A, A^{\prime}$, green). The appearance of the melanopsin-immunoreactive cells with dendrites in stratum 1 of the IPL is consistent with their identity as M1 ipRGCs (Berson et al., 2010). SRIF-immunoreactive processes (red) and melanopsin-immunoreactive dendrites (green) were often in close proximity in stratum 1 of the IPL (Fig. $10 A, A^{\prime}$ ). Rarely occurring SRIF processes in stratum 5 of the IPL were also adjacent to melanopsin-immunoreactive dendrites (Fig. 10A). Some SRIFimmunoreactive processes $(n=4$ retinas; Fig. $10 B)$ and melanopsinimmunoreactive dendrites (Fig. 10B') in whole-mounted retinas were in juxtaposition, and they made multiple contacts in stratum 1 of the IPL (Fig. 10B", arrows). In contrast to the numerous contacts between the SRIF- and TH-immunoreactive amacrine cell processes in stratum 1 of the IPL, there were fewer SRIF-immunoreactive processes adjacent to melanopsin-immunoreactive dendrites.

To test whether the contacts between SRIF amacrine cell processes and melanopsin ipRGC dendrites were nonrandom, we quantified the fluorescent density of contacts between SRIF processes and melanopsin dendrites in a $3 \mathrm{D}$ reconstruction of an image stack taken through the IPL (Fig. 10C, $C^{\prime}$ ). The number of contacts between the SRIF processes and melanopsin dendrites was significantly more in the original reconstruction $\left(0^{\circ}\right)$ compared with the rotated $\left(90^{\circ}\right.$, $180^{\circ}$, and $270^{\circ}$ ) reconstructions (Fig. $10 D, E ; n=11$ retinas; $p<$ $0.03,0.04$, and 0.04 ). The decrease in percentage fluorescent density of contacts on rotation was consistent when normalized to melanop$\sin \left(0.90 \pm 0.39 \%\right.$ at $0^{\circ}, 0.12 \pm 0.05 \%$ at $90^{\circ}, 0.09 \pm 0.05 \%$ at $180^{\circ}$, and $0.10 \pm 0.05 \%$ at $270^{\circ} ; n=11$ retinas) or SRIF fluorescent density $\left(1.34 \pm 0.36 \%\right.$ at $0^{\circ}, 0.66 \pm 0.33 \%$ at $90^{\circ}, 0.69 \pm 0.37 \%$ at $180^{\circ}$, and $0.68 \pm 0.31 \%$ at $270^{\circ} ; \mathrm{N}=11$ retinas; Fig. $\left.10 D, E\right)$. On this basis, we conclude that contacts between the apposing SRIF- and melanopsin-immunoreactive processes in stratum 1 of the IPL are putative sites of neurotransmission between SRIF amacrine cells and M1 ipRGCs.

\section{Localization of sst $_{4}$ receptors on ipRGCs}

To determine whether receptors for direct modulation by SRIF of M1 ipRGCs existed, we tested for the expression of sst immuno- $_{4}$ reactivity in transverse retinal sections. We used the OPN4EGFP mouse retinas (Schmidt et al., 2008) and processed them for $s t_{4}$ immunolabeling. sst $_{4}$ immunoreactivity was expressed weakly by medium- and large-diameter somata in the GCL and more strongly expressed on numerous primary, as well as secondary dendrites in the IPL. sst $_{4}$ immunoreactivity was present robustly in axons of the nerve fiber layer $(n=4$ retinas; Fig. $11 \mathrm{~A}$, red). EGFP-labeled somata were located in the GCL, and their dendrites extended from the GCL across the IPL (Fig. 11B') to stratum 1 of the IPL (Fig. 11C'). The EGFP-labeled cell somata

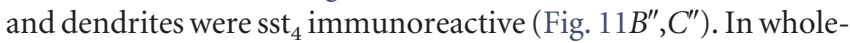
mount OPN4-EGFP retinas, all EGFP fluorescent cells were sst immunoreactive (data not shown). Collectively, our data suggest that sst $_{4}$ is expressed by multiple ganglion cell types, including the EGFP-labeled ipRGCs.

\section{Discussion}

The DA amacrine cell-M1 ipRGC microcircuit provides reciprocal intraretinal interactions that participate in light adaptation and non-image-forming vision. Our results indicate that both cell types can be inhibited directly by the wide-field SRIF amacrine cell output acting postsynaptically via two distinct SRIF receptor subtypes, $s_{2} t_{2 \mathrm{~A}}$ and $\mathrm{sst}_{4}$, expressed by DA amacrine cells and ipRGCs, respectively. In addition to attenuating the intrinsic light response of M1 ipRGCs, we found that SRIF differentially increased $\mathrm{K}^{+}$currents and decreased $\mathrm{Ca}^{2+}$ currents in both DA amacrine cells and M1 ipRGCs. These modulatory actions are inhibitory, the former acting to hyperpolarize the cell and reduce action potential generation, and the latter acting to decrease calcium-mediated transmitter release. SRIF produces similar modulatory actions on voltagegated $\mathrm{K}^{+}$and $\mathrm{Ca}^{2+}$ channel currents in photoreceptors, bipolar cells, and other ganglion cells (Johnson et al., 1998; Akopian et al., 2000; Petrucci et al., 2001; Farrell et al., 2010), suggesting that SRIF signaling in the retina is inhibitory.

The parallel inhibitory actions of SRIF would compensate for the disinhibition of M1 ipRGCs, which arises from SRIFmediated inhibition of DA amacrine cells (Fig. 12). In other words, when SRIF amacrine cells inhibit DA amacrine cells, the DA amacrine cells release less inhibitory signal onto the M1 ipRGCs, in effect maintaining the M1 ipRGCs in a more excitatory state. To counteract this action, SRIF provides parallel inhibition onto M1 ipRGCs, which would add back the lost inhibitory influence. As a result, SRIF actions on DA amacrine cells could proceed with tuning retinal DA levels without leading to a destabilization of the M1 ipRGC light response. The identity of the long sought interneuronal subtype responsible for inhibition of DA amacrine cells (Perez-Leon et al., 2006; Wong et al., 2007; Atkinson et al., 2013; Newkirk et al., 2013) is revealed to be the rarely occurring SRIF-containing wide-field amacrine cell described in this report.

\section{SRIF inhibits excitability and intrinsic photosensitivity}

Both DA amacrine cells and M1 ipRGCs spike spontaneously, leading to sustained neurotransmitter release (Gustincich et al., 


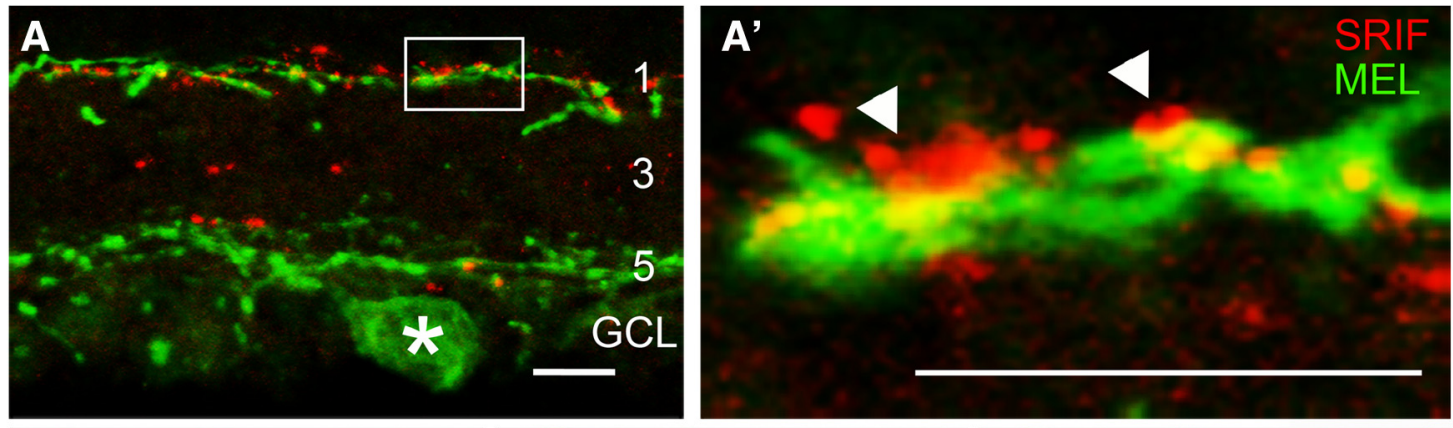

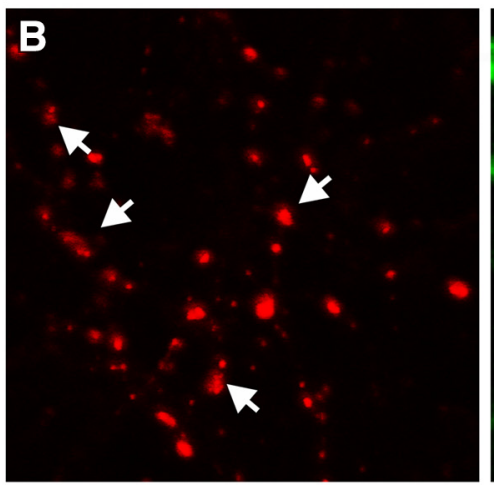
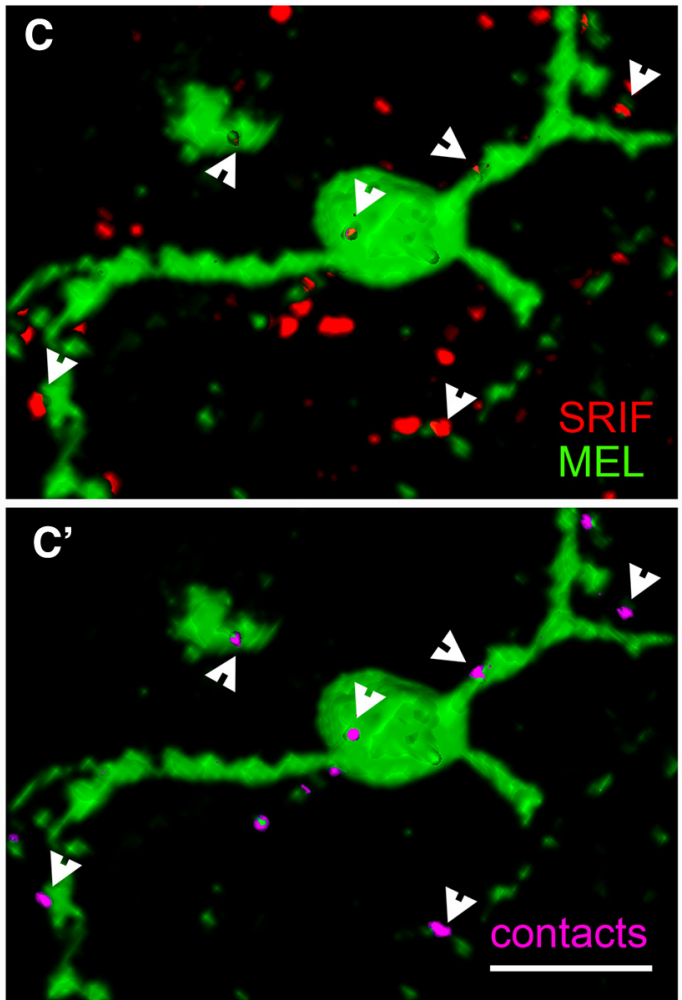
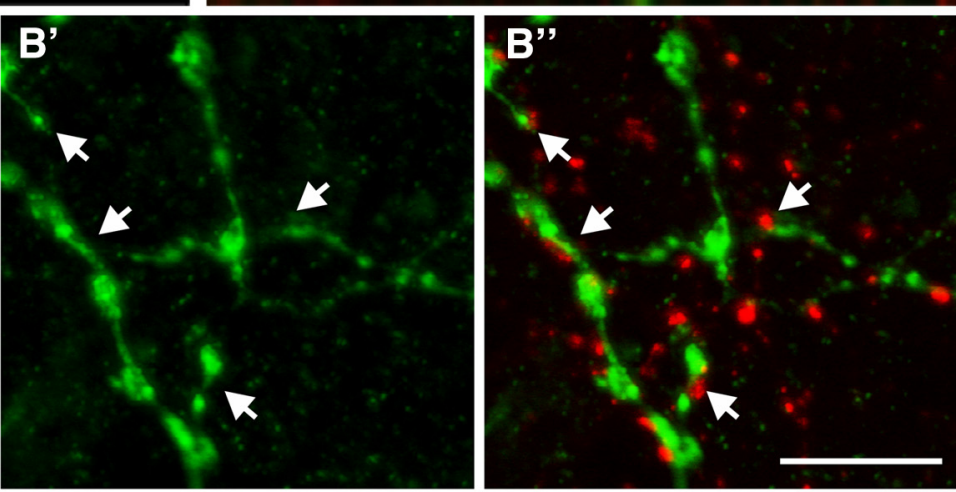

D

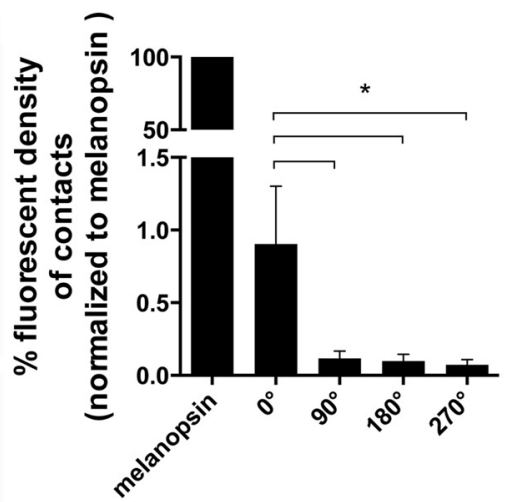

$\mathbf{E}$

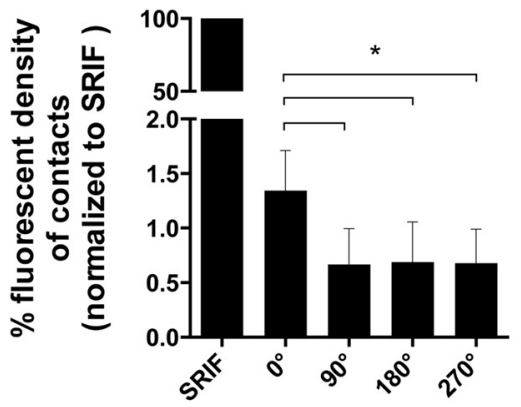

Figure 10. SRIF and melanopsin immunostaining show the juxtaposition of SRIF amacrine cell processes and M1 ipRGC dendrites in stratum 1 of the IPL. $\boldsymbol{A}$, SRIF amacrine cell processes (red) are mainly in stratum 1 of the IPL and a few processes are in strata 3 and 5 of the IPL. A melanopsin-immunoreactive somata (asterisk) and its dendrites in strata 1 and 5 of the IPL. $\boldsymbol{A}^{\prime}$ is a magnification of the inset in $\boldsymbol{A}$ showing melanopsin ipRGC dendrites and SRIF amacrine cell processes forming contacts in stratum 1 of the IPL. $\boldsymbol{B}$, SRIF-immunoreactive varicose processes in stratum 1 of the IPL in a whole mount. $\boldsymbol{B}^{\prime}$, Melanopsin immunoreactivity shows robust labeling of melanopsin ipRGC varicose dendrites. $\boldsymbol{B}^{\prime \prime}$, Merged images show close contacts between SRIF amacrine cell processes often near the varicosities of the M1 ipRGC dendrites. C, A 3D reconstruction of SRIF processes and melanopsin dendrites from an image stack taken through the IPL of a retinal whole mount shows many punctate SRIF amacrine cell processes near a displaced melanopsin-immunoreactive ipRGC somata and dendrites. $\boldsymbol{C}^{\prime}$, Omitting the red channel that labeled SRIF amacrine cells reveals the contacts (pink) formed with melanopsin ipRGC somata and dendrites. Arrows show the contacts between SRIF amacrine cell processes and melanopsin ipRGC dendrites. $\boldsymbol{D}$, Quantification of fluorescent density created from the contacting processes was normalized to the fluorescent density of the melanopsin immunoreactivity. Rotated images had significantly less fluorescent density generated from the contacting processes. $\boldsymbol{E}$, Fluorescent density of the contacts was also normalized to the fluorescent density of SRIF immunoreactivity. Fluorescent density of contacts after rotation was significantly less than un-rotated image. Scale bars, $10 \mu \mathrm{m}$. ${ }^{*} p<0.05$. 
1997; Feigenspan et al., 1998; Zhao et al., 2014). The spontaneous spiking of DA amacrine cells was reduced in the presence of SRIF and L-054,264, and M1 ipRGCs decreased their spiking in the presence of SRIF and L-803,087. These reductions in excitability caused by SRIF in both cell types underscore the inhibitory nature of SRIF modulation and are likely mediated principally by the $\mathrm{K}^{+}$channel enhancement induced by SRIF. Adding to this action, an SRIF-induced $\mathrm{Ca}^{2+}$ current attenuation was also established here, which would reduce the release of neurotransmitter by both cell types. In the case of M1 ipRGCs, this would reduce release of the excitatory neurotransmitter glutamate onto DA amacrine cells (Zhang et al., 2008, 2012; Atkinson et al., 2013), as well as their central retinal recipient nuclei (Gooley et al., 2001; Engelund et al., 2010; Gompf et al., 2015). In the case of DA amacrine cells, $\mathrm{Ca}^{2+}$ channel inhibition would reduce the release of DA, as well as their cotransmitter GABA (Contini and Raviola, 2003; Hirasawa et al., 2009, 2012).

When comparing the modulatory effects of SRIF, L-803,087, SKF38393, and SCH23390 on intrinsic melanopsin-based light response in M1 ipRGCs, we found that the actions of SRIF were performed directly on the M1 ipRGCs and were not mediated in any manner by the DA amacrine cell. We showed that the intrinsic light response of M1 ipRGCs is inhibited by DA acting directly on $\mathrm{D}_{1}$ receptors in mouse retina, consistent with findings in the rat retina (Van Hook et al., 2012), and we showed that SRIF also inhibited the melanopsin-based light response in M1 ipRGCs. Inhibition of the M1 ipRGC photocurrent by the selective sst ${ }_{4}$ agonist L-803,087 and the D1 agonist SKF38393 individually means that the inhibitory inputs from DA amacrine cells and SRIF amacrine cells act independently on M1 ipRGCs.

Coapplication of SRIF and SKF38393, or L-803,087 and SKF38393 did not produce an additive reduction of the M1 ipRGC photocurrent, possibly reflecting a common signaling pathway that increases cAMP (Feigenspan and Bormann, 1994). In addition, blocking DA responses in M1 ipRGCs with the $D_{1}$ antagonist SCH23390, which might be expected to increase the light response, had no effect, possibly because of a low basal release of DA from DA amacrine cells and the possibility of other inhibitory pathways converging on the M1 ipRGC. We also found that L-803,087, applied in the presence of SCH23390, continued to significantly attenuate the M1 ipRGC photocurrent to the same degree as L-803,087 alone. These data highlight the non-additive and independent inhibitory actions of DA and SRIF on M1 ipRGC photocurrents.

It is also interesting to note that the parallel inhibitory actions of SRIF occur at different mechanistic levels. SRIF and DA both inhibit M1 ipRGCs but via different intracellular mechanisms: SRIF modulates voltage-gated $\mathrm{K}^{+}$and $\mathrm{Ca}^{2+}$ channel currents (Farrell et al., 2010), whereas DA decreases $\mathrm{Na}^{+}$currents and increases hyperpolarization-

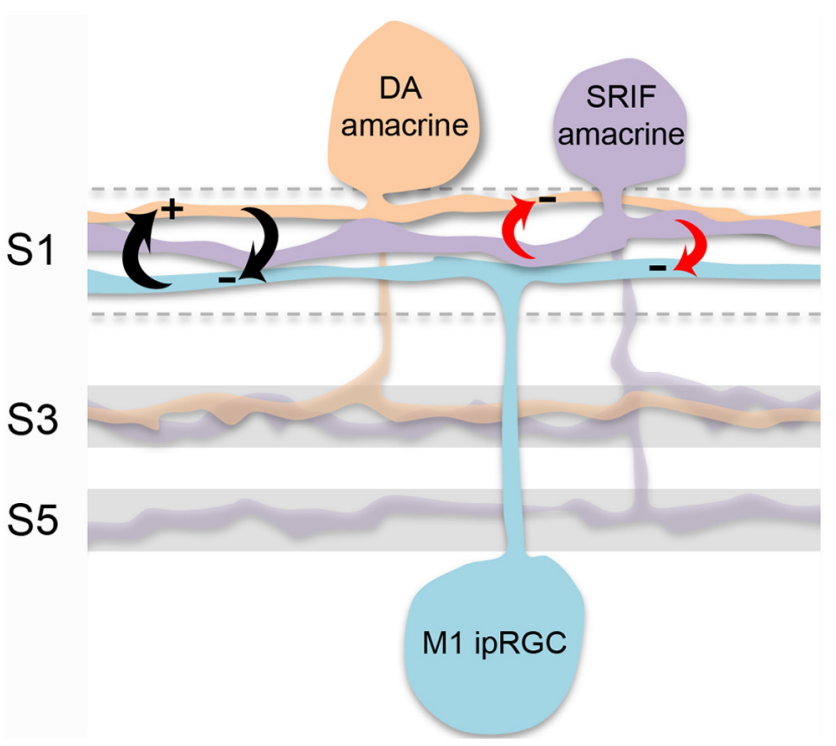

Figure 12. Regulation of the DA amacrine cell-M1 ipRGC microcircuit by SRIF amacrine cells. The principle contacts at which SRIF amacrine cells mediate parallel inhibition (red arrows) of DA amacrine cells and M1 ipRGCs (whose reciprocal interactions are denoted with black arrows) occur within stratum 1 (S1) of the IPL. Few contacts occur in strata 3 (S3) and 5 (S5). SRIF amacrine cells target M1 ipRGCs for inhibition in a manner that can compensate for the loss of DA-mediated inhibition of M1 ipRGCs, which occurs when SRIF inhibits the DA amacrine cell. 
activated cation currents (Hayashida and Ishida, 2004; Chen and Yang, 2007; Hayashida et al., 2009; Van Hook et al., 2012).

\section{Infrastructure for distinct sst receptor-mediated inhibition}

In addition to the presumed locations for reciprocal interactions of DA amacrine cells and M1 ipRGCs in stratum 1 of the IPL (Østergaard et al., 2007; Vugler et al., 2007; Wong et al., 2007; Zhang et al., 2008; Van Hook et al., 2012), there are other GABAergic, glycinergic, and glutamatergic cells ramifying in stratum 1 of the IPL that could provide regulatory signaling of the SRIF-DA-ipRGC microcircuit (Dumitrescu et al., 2009; Contini et al., 2010; Newkirk et al., 2013). Whether other cells modulate this microcircuit and alter the light response of the M1 ipRGC or adjust their glutamatergic signaling (Gompf et al., 2015) to DA amacrine cells is an important question for future study.

Here we showed that the processes of the SRIF amacrine cells and DA amacrine cells are aligned closely and form fascicles in stratum 1 of the IPL and that they are also in close proximity to the dendrites of M1 ipRGCs. These findings are congruent with our evidence supporting synaptic communication between SRIF amacrine cells and DA amacrine cells, as well as SRIF amacrine cells and M1 ipRGCs.

We confirmed that DA amacrine cells express the sst ${ }_{2 \mathrm{~A}}$ receptor (Johnson et al., 1998; Helboe and Møller, 1999; Cristiani et al., 2002; Thermos, 2003). Although others have reported localization of sst ${ }_{5}$ receptors on DA amacrine cells (Ke and Zhong, 2007; Wu et al., 2012; Chen et al., 2014), we have not found sst $t_{5}$ expression on DA amacrine cells (data not shown); thus, we focused on the physiological effects of sst ${ }_{2 \mathrm{~A}}$, and additional studies will be needed to confirm localization of sst ${ }_{5}$ and its functional effects on DA amacrine cells. We also showed that M1 ipRGCs express the sst $_{4}$ receptor, corresponding to previous reports that sst ${ }_{4}$ is the only SRIF receptor subtype localized to ganglion cell somata and processes (Cristiani et al., 2002; Farrell et al., 2010). Anatomically, DA amacrine cells and M1 ipRGCs bear the appropriate receptors for modulation by the neuropeptide SRIF, which is solely released from the SRIF amacrine cells.

\section{Alternative regulatory signaling by SRIF and DA amacrine cells}

Although we show that SRIF could mediate parallel inhibition of DA amacrine cells and M1 ipRGCs, SRIF amacrine cells also contain GABA (Cristiani et al., 2002; Thermos, 2003). Additional investigation is needed to explore the implications of the SRIF and GABA coimmunoreactive processes that are apposed to DA amacrine cell or M1 ipRGC processes. Others have shown that GABA-mediated amacrine cell signaling was enhanced in the presence of other cotransmitters, including vasoactive intestinal peptide, DA, and somatostatin (Veruki and Yeh, 1992; Feigenspan and Bormann, 1994; Contini and Raviola, 2003; Hirasawa et al., 2009, 2012). It is possible that the inhibitory effects of SRIF are a means for refining fast GABAergic signaling from the SRIF amacrine cells onto DA amacrine cells and M1 ipRGCs.

\section{Effects of SRIF-mediated inhibition}

Inhibition of the microcircuit (DA amacrine cells-M1 ip RGCs) by SRIF is of special importance because the two cell types mediate critical functions in the visual system. The DA system modulates actions, including circadian photoentrainment, gap junction coupling, and light and dark adaptation (Ruan et al., 2008; Jackson et al., 2012; Jin et al., 2015). M1 ipRGCs, which produce robust lightevoked depolarizations, project to the suprachiasmatic nucleus of the hypothalamus and olivary pretectal nuclei, implicating central regulation of circadian rhythms and pupillary light reflex, respec- tively (Schmidt et al., 2008; Schmidt and Kofuji, 2009). In addition, ipRGCs project to other brain regions that influence sleep, mood, cognition, pain, and addiction (Hattar et al., 2006). Therefore, compensatory inhibition of the M1 ipRGCs could be expected to stabilize its broad actions on targets in the brain and its local targets in the retina.

\section{References}

Akopian A, Johnson J, Gabriel R, Brecha N, Witkovsky P (2000) Somatostatin modulates voltage-gated $\mathrm{K}^{+}$and $\mathrm{Ca}^{2+}$ currents in rod and cone photoreceptors of the salamander retina. J Neurosci 20:929-936. Medline

Atkinson CL, Feng J, Zhang DQ (2013) Functional integrity and modification of retinal dopaminergic neurons in the rd 1 mutant mouse: roles of melanopsin and GABA. J Neurophysiol 109:1589-1599. CrossRef Medline

Belenky MA, Smeraski CA, Provencio I, Sollars PJ, Pickard GE (2003) Melanopsin retinal ganglion cells receive bipolar and amacrine cell synapses. J Comp Neurol 460:380-393. CrossRef Medline

Berson DM, Castrucci AM, Provencio I (2010) Morphology and mosaics of melanopsin-expressing retinal ganglion cell types in mice. J Comp Neurol 518:2405-2422. CrossRef Medline

Chen L, Yang XL (2007) Hyperpolarization-activated cation current is involved in modulation of the excitability of rat retinal ganglion cells by dopamine. Neuroscience 150:299-308. CrossRef Medline

Chen W, Ke JB, Wu HJ, Miao Y, Li F, Yang XL, Wang Z (2014) Somatostatin receptor-mediated suppression of gabaergic synaptic transmission in cultured rat retinal amacrine cells. Neuroscience 273:118-127. CrossRef Medline

Contini M, Raviola E (2003) GABAergic synapses made by a retinal dopaminergic neuron. Proc Natl Acad Sci U S A 100:1358-1363. CrossRef Medline

Contini M, Lin B, Kobayashi K, Okano H, Masland RH, Raviola E (2010) Synaptic input of ON-bipolar cells onto the dopaminergic neurons of the mouse retina. J Comp Neurol 518:2035-2050. CrossRef Medline

Cristiani R, Petrucci C, Dal Monte M, Bagnoli P (2002) Somatostatin (SRIF) and SRIF receptors in the mouse retina. Brain Res 936:1-14. CrossRef Medline

Debertin G, Kántor O, Kovács-Öller T, Balogh L, Szabó-Meleg E, Orbán J, Nyitrai M, Völgyi B (2015) Tyrosine hydroxylase positive perisomatic rings are formed around various amacrine cell types in the mammalian retina. J Neurochem 134:416-428. CrossRef Medline

Dkhissi-Benyahya O, Coutanson C, Knoblauch K, Lahouaoui H, Leviel V, Rey C, Bennis M, Cooper HM (2013) The absence of melanopsin alters retinal clock function and dopamine regulation by light. Cell Mol Life Sci 70:3435-3447. CrossRef Medline

Dowling JE (1991) Retinal neuromodulation: the role of dopamine. Vis Neurosci 7:87-97. CrossRef Medline

Dumitrescu ON, Pucci FG, Wong KY, Berson DM (2009) Ectopic retinal ON bipolar cell synapses in the OFF inner plexiform layer: contacts with dopaminergic amacrine cells and melanopsin ganglion cells. J Comp Neurol 517:226-244. CrossRef Medline

Engelund A, Fahrenkrug J, Harrison A, Hannibal J (2010) Vesicular glutamate transporter 2 (VGLUT2) is co-stored with PACAP in projections from the rat melanopsin-containing retinal ganglion cells. Cell Tissue Res 340:243-255. CrossRef Medline

Farrell SR, Raymond ID, Foote M, Brecha NC, Barnes S (2010) Modulation of voltage-gated ion channels in rat retinal ganglion cells mediated by somatostatin receptor subtype 4. J Neurophysiol 104:1347-1354. CrossRef Medline

Farrell SR, Rankin DR, Brecha NC, Barnes S (2014) Somatostatin receptor subtype 4 modulates L-type calcium channels via Gbetagamma and PKC signaling in rat retinal ganglion cells. Channels (Austin) 8:519-527. CrossRef Medline

Feigenspan A, Bormann J (1994) Facilitation of GABAergic signaling in the retina by receptors stimulating adenylate cyclase. Proc Natl Acad Sci U S A 91:10893-10897. CrossRef Medline

Feigenspan A, Gustincich S, Bean BP, Raviola E (1998) Spontaneous activity of solitary dopaminergic cells of the retina. J Neurosci 18:6776-6789. Medline

Gompf HS, Fuller PM, Hattar S, Saper CB, Lu J (2015) Impaired circadian photosensitivity in mice lacking glutamate transmission from retinal melanopsin cells. J Biol Rhythms 30:35-41. CrossRef Medline

Gooley JJ, Lu J, Chou TC, Scammell TE, Saper CB (2001) Melanopsin in cells of origin of the retinohypothalamic tract. Nat Neurosci 4:1165. CrossRef Medline

Gustincich S, Feigenspan A, Wu DK, Koopman LJ, Raviola E (1997) Control of dopamine release in the retina: a transgenic approach to neural networks. Neuron 18:723-736. CrossRef Medline

Hattar S, Kumar M, Park A, Tong P, Tung J, Yau KW, Berson DM (2006) 
Central projections of melanopsin-expressing retinal ganglion cells in the mouse. J Comp Neurol 497:326-349. CrossRef Medline

Hayashida Y, Ishida AT (2004) Dopamine receptor activation can reduce voltage-gated $\mathrm{Na}^{+}$current by modulating both entry into and recovery from inactivation. J Neurophysiol 92:3134-3141. CrossRef Medline

Hayashida Y, Rodríguez CV, Ogata G, Partida GJ, Oi H, Stradleigh TW, Lee SC, Colado AF, Ishida AT (2009) Inhibition of adult rat retinal ganglion cells by D1-type dopamine receptor activation. J Neurosci 29:1500115016. CrossRef Medline

Helboe L, Møller M (1999) Immunohistochemical localization of somatostatin receptor subtypes sst 1 and sst2 in the rat retina. Invest Ophthalmol Vis Sci 40:2376-2382. Medline

Hirasawa H, Puopolo M, Raviola E (2009) Extrasynaptic release of GABA by retinal dopaminergic neurons. J Neurophysiol 102:146-158. CrossRef Medline

Hirasawa H, Betensky RA, Raviola E (2012) Corelease of dopamine and GABA by a retinal dopaminergic neuron. J Neurosci 32:13281-13291. CrossRef Medline

Hu C, Hill DD, Wong KY (2013) Intrinsic physiological properties of the five types of mouse ganglion-cell photoreceptors. J Neurophysiol 109: 1876-1889. CrossRef Medline

Jackson CR, Ruan GX, Aseem F, Abey J, Gamble K, Stanwood G, Palmiter RD, Iuvone PM, McMahon DG (2012) Retinal dopamine mediates multiple dimensions of light-adapted vision. J Neurosci 32:9359-9368. CrossRef Medline

Jian K, Barhoumi R, Ko ML, Ko GY (2009) Inhibitory effect of somatostatin-14 on L-type voltage-gated calcium channels in cultured cone photoreceptors requires intracellular calcium. J Neurophysiol 102: 1801-1810. CrossRef Medline

Jin NG, Chuang AZ, Masson PJ, Ribelayga CP (2015) Rod electrical coupling is controlled by a circadian clock and dopamine in mouse retina. J Physiol 593:1597-1631. CrossRef Medline

Johnson J, Wong H, Walsh JH, Brecha NC (1998) Expression of the somatostatin subtype 2A receptor in the rabbit retina. J Comp Neurol 393:93101. CrossRef Medline

Johnson J, Wu V, Wong H, Walsh JH, Brecha NC (1999) Somatostatin receptor subtype 2A expression in the rat retina. Neuroscience 94:675-683. CrossRef Medline

Johnson J, Rickman DW, Brecha NC (2000) Somatostatin and somatostatin subtype $2 \mathrm{~A}$ expression in the mammalian retina. Microsc Res Tech 50: 103-111. CrossRef Medline

Ke JB, Zhong YM (2007) Expression of somatostatin receptor subtype 5 in rat retinal amacrine cells. Neuroscience 144:1025-1032. CrossRef Medline

Ko GY, Ko ML, Dryer SE (2003) Circadian phase-dependent modulation of cGMP-gated channels of cone photoreceptors by dopamine and D2 agonist. J Neurosci 23:3145-3153. Medline

Masland RH (2001) The fundamental plan of the retina. Nat Neurosci 4:877-886. CrossRef Medline

Masland RH (2012) The neuronal organization of the retina. Neuron 76: 266-280. CrossRef Medline

Newkirk GS, Hoon M, Wong RO, Detwiler PB (2013) Inhibitory inputs tune the light response properties of dopaminergic amacrine cells in mouse retina. J Neurophysiol 110:536-552. CrossRef Medline

Østergaard J, Hannibal J, Fahrenkrug J (2007) Synaptic contact between melanopsin-containing retinal ganglion cells and rod bipolar cells. Invest Ophthalmol Vis Sci 48:3812-3820. CrossRef Medline

Pérez de Sevilla Müller L, Sargoy A, Rodriguez AR, Brecha NC (2014) Melanopsin ganglion cells are the most resistant retinal ganglion cell type to axonal injury in the rat retina. PLos One 9:e93274. CrossRef Medline

Perez-Leon JA, Warren EJ, Allen CN, Robinson DW, Brown RL (2006) Synaptic inputs to retinal ganglion cells that set the circadian clock. Eur J Neurosci 24:1117-1123. CrossRef Medline

Petrucci C, Resta V, Fieni F, Bigiani A, Bagnoli P (2001) Modulation of potassium current and calcium influx by somatostatin in rod bipolar cells isolated from the rabbit retina via sst2 receptors. Naunyn Schmiedebergs Arch Pharmacol 363:680-694. CrossRef Medline

Rickman DW, Blanks JC, Brecha NC (1996) Somatostatin-immunoreactive neurons in the adult rabbit retina. J Comp Neurol 365:491-503. CrossRef Medline

Ruan GX, Allen GC, Yamazaki S, McMahon DG (2008) An autonomous circadian clock in the inner mouse retina regulated by dopamine and GABA. PLoS Biol 6:e249. CrossRef Medline

Sakamoto K, Liu C, Kasamatsu M, Pozdeyev NV, Iuvone PM, Tosini G (2005) Dopamine regulates melanopsin mRNA expression in intrinsically photosensitive retinal ganglion cells. Eur J Neurosci 22:3129-3136. CrossRef Medline

Schmidt TM, Kofuji P (2009) Functional and morphological differences among intrinsically photosensitive retinal ganglion cells. J Neurosci 29: 476-482. CrossRef Medline

Schmidt TM, Kofuji P (2011) Structure and function of bistratified intrinsically photosensitive retinal ganglion cells in the mouse. J Comp Neurol 519:1492-1504. CrossRef Medline

Schmidt TM, Taniguchi K, Kofuji P (2008) Intrinsic and extrinsic light responses in melanopsin-expressing ganglion cells during mouse development. J Neurophysiol 100:371-384. CrossRef Medline

Schmidt TM, Chen SK, Hattar S (2011) Intrinsically photosensitive retinal ganglion cells: many subtypes, diverse functions. Trends Neurosci 34: 572-580. CrossRef Medline

Thermos K (2003) Functional mapping of somatostatin receptors in the retina: a review. Vision Res 43:1805-1815. CrossRef Medline

Tornqvist K, Uddman R, Sundler F, Ehinger B (1982) Somatostatin and VIP neurons in the retina of different species. Histochemistry 76:137-152. CrossRef Medline

Van Hook MJ, Wong KY, Berson DM (2012) Dopaminergic modulation of ganglion-cell photoreceptors in rat. Eur J Neurosci 35:507-518. CrossRef Medline

Veruki ML, Yeh HH (1992) Vasoactive intestinal polypeptide modulates GABAA receptor function in bipolar cells and ganglion cells of the rat retina. J Neurophysiol 67:791-797. Medline

Viney TJ, Balint K, Hillier D, Siegert S, Boldogkoi Z, Enquist LW, Meister M, Cepko CL, Roska B (2007) Local retinal circuits of melanopsincontaining ganglion cells identified by transsynaptic viral tracing. Curr Biol 17:981-988. CrossRef Medline

Voigt T, Wässle H (1987) Dopaminergic innervation of A II amacrine cells in mammalian retina. J Neurosci 7:4115-4128. Medline

Vugler AA, Redgrave P, Semo M, Lawrence J, Greenwood J, Coffey PJ (2007) Dopamine neurones form a discrete plexus with melanopsin cells in normal and degenerating retina. Exp Neurol 205:26-35. CrossRef Medline

Vuong HE, Pérez de Sevilla Müller LP, Hardi CN, McMahon DG, Brecha NC (2015) Heterogeneous transgene expression in the retinas of the THRFP, TH-Cre, TH-BAC-Cre and DAT-Cre mouse lines. Neuroscience 307:319-337. CrossRef Medline

White CA, Chalupa LM, Johnson D, Brecha NC (1990) Somatostatinimmunoreactive cells in the adult cat retina. J Comp Neurol 293:134-150. CrossRef Medline

White FJ (1996) Synaptic regulation of mesocorticolimbic dopamine neurons. Annu Rev Neurosci 19:405-436. CrossRef Medline

Witkovsky P (2004) Dopamine and retinal function. Doc Ophthalmol 108: 17-40. CrossRef Medline

Wong KY, Dunn FA, Graham DM, Berson DM (2007) Synaptic influences on rat ganglion-cell photoreceptors. J Physiol 582:279-296. CrossRef Medline

Wu XH, Deng QQ, Jiang SX, Yang XL, Zhong YM (2012) Distribution of somatostatin receptor 5 in mouse and bullfrog retinas. Peptides 33:291-297. CrossRef Medline

Zhang DQ, Stone JF, Zhou T, Ohta H, McMahon DG (2004) Characterization of genetically labeled catecholamine neurons in the mouse retina. Neuroreport 15:1761-1765. CrossRef Medline

Zhang DQ, Zhou TR, McMahon DG (2007) Functional heterogeneity of retinal dopaminergic neurons underlying their multiple roles in vision. J Neurosci 27:692-699. CrossRef Medline

Zhang DQ, Wong KY, Sollars PJ, Berson DM, Pickard GE, McMahon DG (2008) Intraretinal signaling by ganglion cell photoreceptors to dopaminergic amacrine neurons. Proc Natl Acad Sci U S A 105:14181-14186. CrossRef Medline

Zhang DQ, Belenky MA, Sollars PJ, Pickard GE, McMahon DG (2012) Melanopsin mediates retrograde visual signaling in the retina. PLoS One 7:e42647. CrossRef Medline

Zhao X, Stafford BK, Godin AL, King WM, Wong KY (2014) Photoresponse diversity among the five types of intrinsically photosensitive retinal ganglion cells. J Physiol 592:1619-1636. CrossRef Medline 